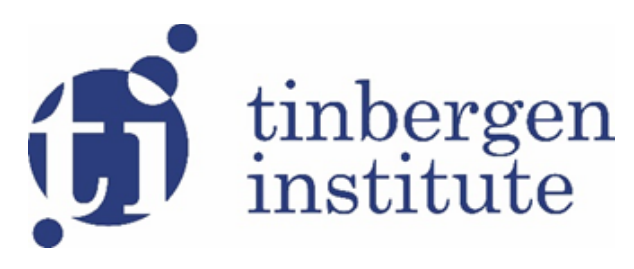

TI 2020-026/V

Tinbergen Institute Discussion Paper

\title{
Election systems, the "beauty premium" in politics, and the beauty of dissent
}

Niklas Potrafke ${ }^{1}$

Marcus Rösch ${ }^{2}$

Heinrich Ursprung ${ }^{3}$

\footnotetext{
${ }^{1}$ University of Munich and CESifo

2 Erasmus University Rotterdam, Tinbergen Institute

3 University of Konstanz
} 
Tinbergen Institute is the graduate school and research institute in economics of Erasmus University Rotterdam, the University of Amsterdam and Vrije Universiteit Amsterdam.

Contact: discussionpapers@tinbergen.nl

More TI discussion papers can be downloaded at https://www.tinbergen.nl

Tinbergen Institute has two locations:

Tinbergen Institute Amsterdam

Gustav Mahlerplein 117

1082 MS Amsterdam

The Netherlands

Tel.: +31(0)205984580

Tinbergen Institute Rotterdam

Burg. Oudlaan 50

3062 PA Rotterdam

The Netherlands

Tel.: +31(0)10408 8900 


\title{
Election systems, the "beauty premium" in politics, and the beauty of dissent
}

\author{
Niklas Potrafke ${ }^{1}$ \\ University of Munich \\ ifo Institute \\ Marcus Rösch² \\ Erasmus University of Rotterdam \\ Heinrich Ursprung ${ }^{3}$ \\ University of Konstanz
}

May 2020

\begin{abstract}
We ask three questions. First, do election systems differ in how they translate physical attractiveness of candidates into electoral success? Second, do political parties strategically exploit the "beauty premium" when deciding on which candidates to nominate, and, third, do elected MPs use their beauty premium to reap some independence from their party? Using the German election system that combines first-past-the-post election with party-list proportional representation, our results show that plurality elections provide more scope for translating physical attractiveness into electoral success than proportional representation. Whether political parties strategically use the beauty premium to optimize their electoral objectives is less clear. Physically attractive MPs, however, allow themselves to dissent more often, i.e. they vote more often against the party line than their less attractive peers.
\end{abstract}

Keywords: attractiveness of politicians, safe district, party strategies, electoral success, electoral system

JEL codes: D72, J45, J70

We thank Arye Hillman, Laurine Martinoty, Pierre-Guillaume Méon, Panu Poutvaara, Zeev Shtudinerfor, Mustafa Yeter, and three anonymous referees for valued comments. Helpful feedback was received from conference participants at the 27th Silvaplana Workshop on Political Economy 2018, the 2019 annual meeting of the European Public Choice Society in Jerusalem, the 2019 Ariel Conference on the Political Economy of Economic Policy, and seminar participants at the Sorbonne Université and Jadavpur University (Kolkata).

This paper has been accepted for publication in the European Journal of Political Economy.

1 University of Munich, Center for Economic Studies, Schackstr. 4/I, D-80539 Munich, Germany; Ifo Institute, Ifo Center for Public Finance and Political Economy, Poschingerstr. 5, D-81679 Munich, Germany, Phone: +49 899224 1319, Fax: +49 89907795 1319, E-mail: potrafke@ifo.de

2 Erasmus University Rotterdam, Erasmus School of Economics, Department of Applied Economics, Box 1738, 3000 DR Rotterdam, The Netherlands, E-mail: rosch@ese.eur.nl

${ }^{3}$ Corresponding author: University of Konstanz, Department of Economics, Box 138, D-78457 Konstanz, Germany, Phone: +49 753188 2332, Fax: +49 753188 3110, E-mail: heinrich.ursprung@uni-konstanz.de 


\section{Introduction}

Beauty pays. This is a commonplace truth. Physically attractive people experience benefits in almost all areas of life. Cute babies are better cared for, teachers pay more attention to attractive school children, and attractive adults are more likely to obtain good jobs, to be promoted, to earn high incomes, to obtain loans, to be elected to public office, to be acquitted as defendants, to be given lighter sentences when convicted, to be treated favorably in all kinds of social intercourse, and to enjoy physically attractive and cultivated life companions (Hamermesh 2011, Mazzella and Feingold 1994). Physical attractiveness may, however, also give rise to violent victimization (Savolainen et al. 2020). Technically speaking, those benefits often constitute economic rents; in everyday language they may well be put on a level with discrimination. Daniel Hamermesh, never at a loss for asking uncomfortable questions, contemplates, tongue in cheek, whether the ugly should not be helped by government-sponsored affirmative action programs. ${ }^{4}$

We restrict ourselves to the political sphere and ask to what extent specific electoral rules alleviate the effect of the candidates' physical attractiveness on election outcomes. If the "beauty premium" cannot be neutralized by institutional measures, two questions arise. First, do political parties strategically exploit this effect when they nominate candidates in general elections, and, second, do elected MPs take their beauty premium into account when deciding whether to dissent from their party line. We will address these issues as well.

General elections are an excellent field for investigating biases induced by physical attractiveness because we deal here with low-cost decisions in the sense of Kirchgässner (1992). In low cost environments biased individual behavior, even if it proves to be dysfunctional at the aggregate level, is not subject to strong self-correcting forces and can, therefore, persist for a long time. Individual vote decision in general

\footnotetext{
${ }^{4}$ For our lettered readers: this line of thought may be capricious, but it is actually neither new, nor does it envision the worst possible dramaturgic turn of events as demanded by the distinguished dramatist Friedrich Dürrenmatt (1962, point 3). This is what L. P. Hartley's novel Facial Justice does (Hartley 1960). In this novel, the Ministry of Facial Justice sends facially over privileged persons to the Equalization Centre to undergo betafication, i.e. they are endowed with a synthetic beta face that helps them to better blend in with the great unwashed.
} 
elections are, of course, low cost because the vast majority of the electorate shows little interest in political affairs (Caplan 2011) and, perhaps more importantly, because the individual voter's influence on the outcome is virtually zero (Tullock 1971). Both of these features induce many voters to remain "rationally ignorant" about the alternative candidates' or parties' agendas (Downs 1957). Rationally ignorant voters, if they attempt to vote in line with their instrumental objectives at all, base their decision on whatever expedient information they bump into. They may consciously or unconsciously look out for cheap cues that indicate candidate competence. Empirical evidence indicates that attractive people are perceived to be more competent than less attractive people (Jackson et al. 1995). It is therefore reasonable to assume that many voters are beautybiased even if they have instrumental intentions. ${ }^{5}$

The low-cost nature of voting in general elections may, of course, also dispose voters to completely decouple their motives from the outcome of the election and to simply indulge in a quest for self-gratification through the act of voting expressively (Hillman 2010, Hamlin and Jennings 2011). Expressive voters derive utility from expressing support for specific candidates because this lets them demonstrate their affiliation with a group of kindred spirits they want to belong to, or at least be associated with. Whatever identity is supposed to be signaled, the demonstration effect works best if the target candidate radiates popularity, recognizability, likability, dynamism, assertiveness, self-confidence, leadership, intelligence, competence, trustworthiness, and a dashing will to affect a turnaround. All these traits people perceive to be associated with physical attractiveness (Langlois et al. 2000). Expressive voters can therefore also be expected to be beauty biased.

We use data from German general elections because the German mixed election system combines the two extreme and most widely used election rules, i.e. plurality elections and proportional representation, and does so in one round of voting by one and the same electorate. This feature helps to compare the two systems regarding how

\footnotetext{
5 Some scholars have found positive, albeit economically small, correlations between physical traits and actual competence (see, for example, Case and Paxson 2008). In large electorates one may, therefore, conjecture that beauty-biased voters will, as a rule, elect competent candidates. But this conjecture rests on two spurious assumptions: first, that the covariance of physical attractiveness and competence is sufficiently large and, second, that individual judgments are formed independently (as called for in Condorcet's jury theorem) which is, however, not likely to be satisfied (as indicated by the literature spawned by the Asch 1951 experiment).
} 
physical attractiveness of candidates translates into electoral success. ${ }^{6}$ The mixed system also allows us to explore whether political parties strategically exploit the beauty premium by conditioning the allocation of candidates to electoral districts and/or the party list on the candidates' physical attractiveness.

Each federal state (Land) comprises, as of 2017, between 4 (Saarland) and 64 (North Rhine-Westphalia) single-member electoral districts. The candidates running in these districts for direct election are highly visible because they are used by their parties as crowd pullers. The direct candidates' physical attractiveness is therefore expected to play a significant role for electoral success. The candidates running on the party lists issued in each state (Land) are much less visible. Their prospects of being elected depends on how high-up they are placed by their party on the party state-list, on the share of list votes obtained by their party in the respective state (Land), and on how many candidates of their party are elected directly. Advertising themselves as individual candidates thus does not help them in their bid for election. Apart from the top candidates who are well known anyway, voters hardly take in the appearance of list candidates into account. We thus conjecture that the beauty effect is much stronger in the direct election tier than in the proportional representation (party-list) tier where the effect might not be present at all.

The results are as follows. First, we find that physically attractive candidates, especially those nominated by the catch-all parties, the Christian-conservative CDU/CSU and the social democratic SPD, do better than less attractive candidates in direct elections. The physical attractiveness of the prominent list candidates, on the other hand, does not turn out to be related to the all-important second vote share that determines the proportional distribution of seats, and how much money the parties receive from the government. These results are based on regressions of our full sample and consider dummy variables of the candidates' party affiliation. Second, we find that the MPs of catch-all parties who only ran for office in electoral districts, are on average physically more attractive than their peers who ran on the party list as well. This result is compatible with the presumption that the catch-all parties strategically exploit the beauty effect identified and summarized by our first result. We do, however, not find

\footnotetext{
6 Maaser and Stratmann (2018) also use this especially informative setting for studying legislators' behavior under majoritarian vs. proportional representation election rules. They investigate the effect of the election rules on which committees the MPs are selected into.
} 
that the catch-all parties nominate physically attractive candidates in contested districts. On the contrary: it rather appears that physically attractive candidates have the political clout to run in safe electoral districts. German political parties thus do not tend to maximize electoral success by strategically allocating their beauty resources to specific districts in the same way as parties allocate their financial resources (Stromberg 2008).

We also ask whether physical attractiveness relates to how politicians behave when they are elected to public office. In parliamentary democracies, this question is not easy to answer if one restricts one's attention to the voting behavior of MPs because party discipline does not allow a great deal of variation in voting behavior across members of parliamentary fractions. Moreover, in the German Bundestag, individual voting behavior is only documented for roll-call votes. We therefore use the relatively few instances in which MPs dissent in roll-call votes from the party line and find that physically attractive MPs are indeed more likely to dissent than physically less attractive MPs. This result is driven by directly elected MPs; the physical attractiveness of list-MPs has no power in explaining dissension from the party line.

\section{Literature review}

The empirical evidence supporting the view that physical attractiveness increases the candidates' electoral success is overwhelming. The proposition applies to important and unimportant elections (Buckley et al. 2007, Banducci et al. 2008), to undistinguished electorates and extremely sophisticated ones (such as the members of the American Economic Association, Hamermesh 2006). The beauty premium appears, however, to be most pronounced for voters who show little interest in politics and are poorly informed (Hart et al. 2011, King and Leigh 2009, and Lenz and Lawson 2011). Beauty premiums have been identified in many countries with different election systems and by using different empirical strategies, including laboratory and field experiments (Ahler et al. 2017). ${ }^{7}$ Among the laboratory experiments, the arguably most surprising ones are

\footnotetext{
7 Country studies include King and Leigh (2009) for Australia, Lawson et al. (2010) for Brazil and Mexico, Efrain and Patterson (1974) for Canada, Berggren et al. (2010) for Finland, Jäckle and Metz (2017) for Germany, Buckley et al. (2007) for Ireland, Lutz (2010) for Switzerland, Banducci et al. (2003) for nonpartisan elections in Great Britain, and Todorov et al. (2005) for the United States.
} 
those showing that small children are well able to predict electoral success when shown pictures of candidates for public office (Antonakis and Dalgas 2009) and experiments documenting that voters draw appearance-based trait inferences within split seconds (Olivola and Todorov 2010). The effects identified in real elections are sizable and may in some instances have influenced the election outcome (Klein and Rosar 2005). Some studies find the beauty premiums to be larger for male candidates and for challengers (King et al. 2009).

Observers can discern the political ideology of candidates running for public offices with above-chance accuracy (Samochowiec et al. 2010, Rule and Ambady 2010, Olivola and Todorov 2010). When observers misjudge a candidate's ideology, this can often be attributed to the fact that they are likely to ascribe their own political views to attractive candidates (Herrmann and Shikano 2015). Licata and Méon (2016) investigate how visual cues are processed to arrive at an assessment of the candidates' political ideology.

The empirical evidence for Germany is largely in line with the findings for other countries. Statistically and substantively significant beauty premiums have been identified for single-member constituency candidates in state legislature elections (Rosar et al. 2008) and in federal elections (Klein and Rosar 2005, Rosar and Klein 2015, Jäckle and Metz 2017). The dependent variable used by Jäckle and Metz (2017) is the difference between the vote share of the winner and the runner-up, and their main explanatory variable is specified as the relative difference in the appearance scores between these two candidates. This study leaves a particularly strong impression because it uses a host of covariates that are also interacted with the explanatory variables (attractiveness, competence, and likeability) to tease out which features of the contestants may drive the results. It turns out that only the incumbency status and age difference between the winner and the runner-up influence the beauty premium. Apart from the direct mechanism working through the ever-present campaign pictures, Maurer and Schoen (2010) have shown that newspapers cover attractive direct candidates more frequently and more favorably than less attractive ones. Moreover, the physical attractiveness of the parties' top candidates, i.e. the candidates who are earmarked to head the respective parliamentary group (caucus) or, if the party is 
victorious, to become prime minister, ${ }^{8}$ influences their party's overall electoral success. Using 70 state elections between 1990 and 2008, Rosar (2009) shows that the beauty aura of top-candidates indeed spreads to their party's vote share.

Rosar (2009) also investigates whether differences in the design of the electoral systems across states and time influence the extent to which the physical attractiveness of the top-candidates translates into electoral success in general elections as measured by the respective parties vote shares. He finds no statistically significant effect, which is perhaps not surprising since the electoral systems in all German federal states are variant forms of the proportional representation system. In an even more challenging context, Rosar and Klein (2010) compare the influence of physical attractiveness on electoral success in three countries with markedly different political cultures and institutions (France, Germany, and the United Kingdom). It turns out that these differences notwithstanding, the beauty premium of directly elected candidates to the respective national parliaments does not appear to be systematically influenced by the cultural or institutional environment. Both of these studies show that it is a real challenge to identify institutional factors of election systems that are likely to mediate the beauty premium. This research question can only be answered if a suitable basis of comparison is available. This basis of comparison needs to encompass sufficiently diverse systems working in sufficiently similar political environments.

The German mixed election system provides the possibility for such a comparison. Stockemer and Praino (2017) focus on the largest German state (North Rhine Westphalia), find that physically attractive candidates running in the 2013 federal election profited only in the direct plurality election tier from a beauty premium; in the tier based on closed-list proportional representation, physical attraction did not pay. Our study starts off with a similar approach, uses however federal election data for four general elections and all of Germany. We proceed in two steps. First, we confirm with more data and different econometric techniques Stockemer and Praino's (2017) result that direct plurality elections give rise to statistically significant beauty premiums, whereas proportional representation elections based on closed party lists do not. In a second step, we investigate whether this idiosyncratic feature of the mixed election system is strategically exploited by political parties seeking maximum representation in

\footnotetext{
${ }^{8}$ Top candidates are, as a rule, placed first on the party lists.
} 
parliament. Whether the parties use the beauty premium as a strategic instrument in candidate selection has so far only been touched upon in the literature. Berggren et al. (2017) find, for example, that rightwing parties tend to nominate better looking politicians. They speculate that when it comes to selecting candidates, rightwing parties favor physically attractive candidates more than leftwing parties because voters use physical attractiveness as a cue for conservatism, implying that attractiveness provides rightwing candidates with a double dividend: the beauty premium and the additional advertisement of their rightwing ideology.

A research question that has, so far, not attracted a great deal of attention is whether the physical attractiveness also plays a role after politicians have been elected to parliament. In the context of party-line voting, a substantial number of studies have, however, focused on a question that is related to our subject matter. These studies investigate whether directly elected MPs are more likely to dissent from the party line than MPs elected through a proportional representation system. When comparing countries using pure majoritarian election systems with countries using pure proportional representation systems, differences with respect to party discipline are evident: in majoritarian systems, MPs are more dependent on their constituency and are, consequently, more likely to deviate from the party line if the party line is not compatible with the views of the constituency. ${ }^{9}$ In mixed systems, the empirical evidence is not quite as clear-cut. Stratmann (2006) examines deviation from the party line in the German Bundestag in the period 1949-1990 and found that directly elected MPs dissented more often than MPs elected via party lists. Sieberer (2010) and Sieberer and Ohmura (2020) find similar results for the 2005-2009 and 1949-2013 period, whereas Becher and Sieberer (2008) find no differences in the 1983-1994 period. ${ }^{10}$

\footnotetext{
9 To enforce party discipline, dissenters can, of course, be punished by denying them re-nomination (direct candidates) or by putting list candidates on an unpromising list place (Galasso and Nannicini 2015). Kauder et al. (2017) find however that German parties go to great lengths tolerating deviation from the party line, perhaps to attract different groups of voters who otherwise would vote for another party or abstain for lack of an opportunity to express their political identity.

10 See Thames (2005) and Kunicova and Remington (2008) on party discipline in the Russian State Duma.
} 


\section{Data and descriptive statistics}

\subsection{Data}

We collected information about the candidates elected to Parliament (Bundestag) in the four German federal elections held between 2002 and 2013. Our dataset includes information on gender, birth year, academic degrees, party membership, and the federal state in which the MPs were elected. For MPs who ran for direct election, the dataset also includes information on the electoral district in which they ran and on the vote share of the winner and the runner-up. ${ }^{11}$

We compiled data on the MPs' physical attractiveness by using the MPs' pictures published in "Kürschners Volkshandbuch", an official handbook published for each legislative period. The head-and-shoulder portraits were taken in front of a neutral background with frontal lighting. We asked raters to evaluate the physical attractiveness of the MPs. Presenting head-and-shoulder portraits instead of full-body portraits has been shown to have no influence attractiveness ratings. ${ }^{12}$ The MPs wear business attires and look squarely into the camera. The neutral background and the identical setting constrain the raters to focus on the candidate and not on superficial matters (Jäckle and Metz 2017). The pictures are black-and-white and do not show any party symbols. To avoid that raters recognize individual MPs, our sample does not include well known cabinet members. ${ }^{13}$ When MPs have served many terms, we include only the observation relating to their most recent term; in general, we thus have for each politician only one observation. ${ }^{14}$ The advantage of using official and standardized pictures (instead of pictures taken, for example, for campaign purposes) admittedly comes at the cost of not having information about the physical attractiveness of all unsuccessful candidates which reduces in some tests the sample size or results in a reduced size of the reference group. We do however believe that this disadvantage is more than compensated for by the advantage of ruling out any information content

\footnotetext{
${ }^{11} 648 \mathrm{MPs}$ who ran in an electoral district were defeated and elected via their party list. The vote shares are reported on the official website (www.bundeswahlleiter.de).

12 Characteristics such as body height appear, however, to have a small influence on perceived attractiveness (Snyder and DeBono 1985).

13 Berggren et al. (2010) notice that an observer's assessment may even be biased if he or she only recognizes a depicted person subconsciously.

14 Exceptions are tests in which winners and runner-ups are compared, such as in the results reported Table 2, column 6, and in Table 6.
} 
apart from physical attractiveness that might be conveyed by pictures taken for whatever ulterior objective.

We recruited 372 raters through Amazon's Mechanical Turk service. We paid around one US Dollar per rater and job that took about three minutes to carry out. Raters could carry out several jobs. American raters are extremely unlikely to recognize the identity of the persons whose physical attractiveness they were asked to evaluate. They were asked to indicate the candidates' physical attractiveness on a ten-point-scale (see appendix A). A job consisted of rating 28-37 MPs (average about 32). We use the average of these individual ratings (about 14 in number), i.e. a measure which is regarded to be unbiased (Patzer 2012)..$^{15}$ The raters were 35.9 years old on average and $60 \%$ of them were male.

We omitted ratings if the rater assigned the same score to all rated persons because such ratings indicate that the rater payed no attention to the pictures and simply finished the job as fast as possible. In the robustness test section, we elaborate on alternative ways of dealing with potentially unreliable raters.

\subsection{Descriptive statistics}

Our full sample comprises the 1223 MPs who served between 2002 and 2013 . The average attractiveness score is 4.36 points on the ten-point scale, the minimum 1.7 and the maximum 8.55. The average attractiveness scores in the four legislative periods ranged between 4.21 and 4.42 , the standard deviations between 1.05 and 1.21 . We also collected data for the preceding legislative period that commenced in 1998 . The average attractiveness score and the standard deviation for this legislative period are 4.56 and 0.78 ; the mean is thus markedly larger and the standard deviation markedly smaller than the means and standard deviations in the four subsequent legislative periods. We speculate that raters in 2018 have had a hard time evaluating 20-year-old portraits showing people with weird hairstyles, eyeglasses, etc. and responded by returning undifferentiated ratings. We therefore decided to stick with the original sample.

Our data confirm findings of previous studies such as Berggren et al. (2010, 2017): leftwing politicians (SPD, Greens, and Left Party) are physically less attractive than rightwing politicians (CDU/CSU and FDP). Table 1 shows that the average

\footnotetext{
15 We use the median of the individual ratings in a robustness test.
} 
attractiveness score of leftwing MPs (4.3) was around 0.12 points smaller than the average attractiveness score of rightwing MPs (4.42). This difference is statistically significant at the $10 \%$ level. A more finely grained distinction of ideologies shows that CSU and FDP MPs, i.e. MPs to the right of the more centrist CDU, are more attractive (4.68) than MPs of the Greens and The Left (4.43) who are to the left of the SPD. The difference in attractiveness between the center-right CDU (4.27) and the center-left SPD (4.23) politicians does not turn out to be statistically significant. But the difference between the far-left parties (Greens and The Left) and the center-left SPD of $4.43-4.23$ $=0.21$ points is statistically significant at the $5 \%$ level. Figure 1 illustrates these results. What is more, the attractiveness of female MPs (4.33) is rated to be very similar than the attractiveness of male MPs (4.36). See Table 1.

Table 1: Two sample t-tests.

Difference in attractiveness scores across political ideologies and gender.

\begin{tabular}{|c|c|c|c|c|c|c|}
\hline & Mean & & Mean & Diff. & Test stat. & Obs. \\
\hline & (1) & (2) & (3) & (4) & (5) & (6) \\
\hline $\begin{array}{l}\text { Rightwing } \\
\text { (CDU/CSU/FDP) }\end{array}$ & 4.42 & $\begin{array}{l}\text { Leftwing } \\
\text { (SPD/Greens/The } \\
\text { Left) }\end{array}$ & 4.30 & $0.12^{*}$ & 1.73 & 1223 \\
\hline \multirow[t]{3}{*}{$\mathrm{CDU} / \mathrm{CSU}$} & 4.35 & SPD & 4.23 & 0.12 & 1.59 & 880 \\
\hline & & Greens/The Left & 4.43 & -0.08 & -0.85 & 696 \\
\hline & & FDP & 4.68 & $-0.33^{* * *}$ & -2.70 & 591 \\
\hline \multirow[t]{2}{*}{ SPD } & 4.23 & CSU/FDP & 4.68 & $-0.45^{* * *}$ & -4.57 & 880 \\
\hline & & Greens/The Left & 4.43 & $-0.21^{* *}$ & -2.18 & 632 \\
\hline $\mathrm{CDU}$ & 4.27 & $\mathrm{CSU}$ & 4.67 & $-0.40^{* * *}$ & -2.95 & 472 \\
\hline CSU/FDP & 4.68 & Greens/The Left & 4.43 & $0.24^{* *}$ & 1.98 & 437 \\
\hline Female & 4.33 & Male & 4.36 & -0.03 & -0.38 & 1223 \\
\hline
\end{tabular}

Notes: ${ }^{*} p<0.10,{ }^{* *} p<0.05,{ }^{* * *} p<0.01$. Columns (1) and (3) show the means of the attractiveness scores (as measured on a ten-point scale, the minimum is 1.7 and the maximum 8.55). Column (4) shows the difference between the means in columns (1) and (3). Column (5) shows the test statistic of a two-sample t-test testing whether the means in column (1) and (3) are equal. Column (6) shows the number of observations. 
Figure 1: Average attractiveness scores across political ideologies

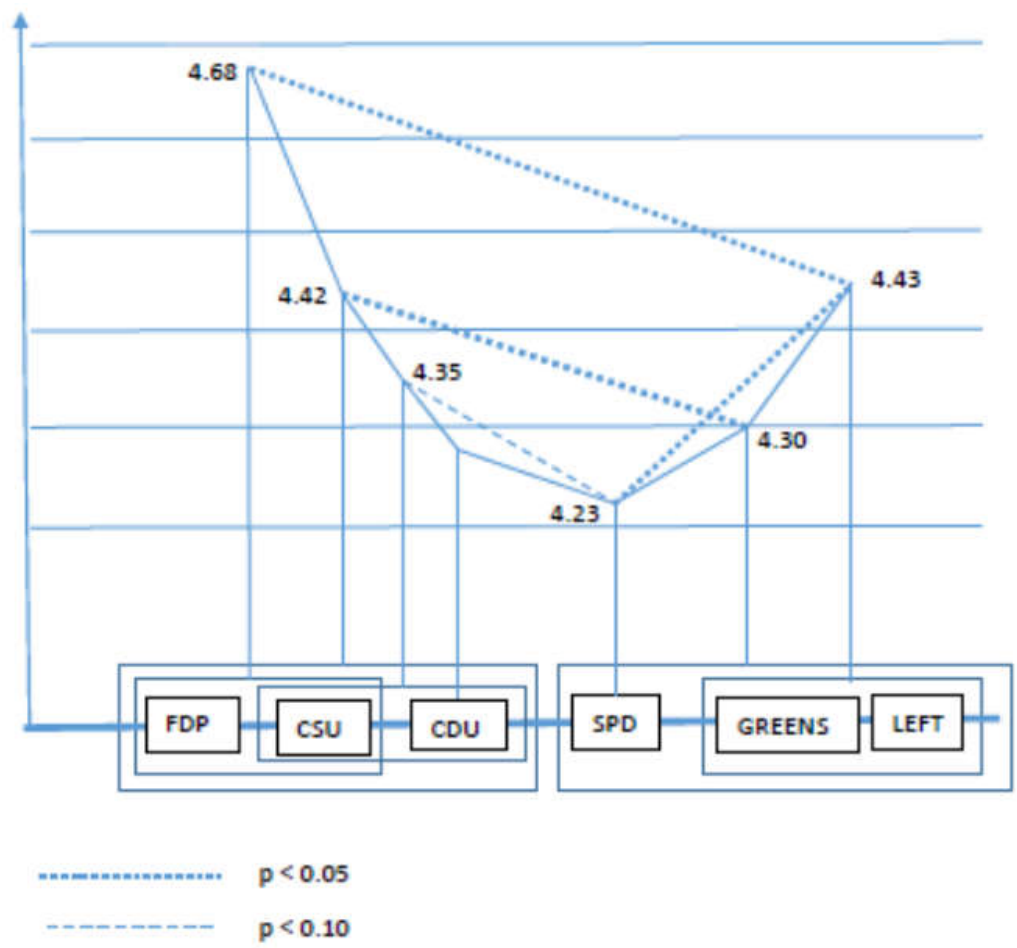

\section{Results}

\subsection{Does beauty pay in first-past-the-post elections?}

In the full sample comprising all MPs who ran in some district for direct election, attractiveness is negatively correlated with the vote share of these contestants. The unconditional correlation coefficient amounts to $r=-0.05$ and is statistically significant at the $10 \%$ level. Notice, that some of these MPs did not succeed in these direct elections and were elected to parliament as list candidates via proportional representation. Before rashly interpreting this result, also notice, that only candidates of the catch-all parties SPD and CDU/CSU are serious contenders; small party contestants have almost no chance of winning (in our observation period only around $2 \%$ of the district elections were won by small party candidates). Small party candidates often enter direct elections only to advertise their parties to obtain a higher vote share in the proportional representation tier of the election which, apart from the seat distribution, also influences the public funds apportioned to the parties. We therefore distinguish between candidates of small and catch-all parties. In our sample, the unconditional correlation between the attractiveness score and the vote share of small party candidates is $r=-0.076(p=0.17)$, for catch-all party candidates it amounts to $r=0.094$ 
$(p=0.0064)$. The difference between the two coefficients is statistically significant at the $1 \%$ level.

An important question is whether the correlation between the candidates' attractiveness and their direct election vote share changes when conditioned on covariates. To examine the conditional correlation, we regress the direct candidates' vote shares on their attractiveness score and other candidate characteristics as control variables. We include the age (logarithmized) and dummy variables assuming the value one when a candidate holds a doctorate, is male, and has been the incumbent in the respective electoral district. We also include district characteristics (unemployment rate, share of male population, district size and population density), political variables (the vote share of the candidate's party in the proportional representation tier of the election at the district level, voter turnout in the electoral district, and dummy variables for the candidates' parties) and dummy variables for the individual legislative periods. We estimate the model with Ordinary Least Squares (OLS) and standard errors robust to heteroscedasticity.

\section{Table 2 about here}

The results for the full sample are reported in Table 2, columns (1) and (2). It transpires that the attractiveness score does not turn out to be statistically significant when no party dummy variables are included (column 1). The attractiveness score variable has, however, a positive sign and is statistically significant at the $1 \%$ level when the party dummy variables are included (column 2). This result confirms the strong correlation between vote shares and party affiliation which simply reflects the fact that the direct plurality elections provide the catch-all parties SPD and CDU/CSU an almost unsurmountable advantage. Not including these party dummies thus gives rise to an omitted variable bias. The party dummies are also correlated with our attractiveness measure: small party MPs are quite attractive, MPs of the catch-all parties less so.

Because the correlation between the direct candidates' attractiveness and vote share varies across party affiliations, we disentangle the beauty effects of catch-all party candidates from the beauty effects of small party candidates. Columns (3) and (4) in Table 2 reports the results. The numerical meaning of the beauty effects reported in column (3) is that the vote share of catch-all party candidates increases in direct 
elections by 0.325 percentage points when the candidate's attractiveness score increases by one point. Given the mean attractiveness score of catch-all party candidates of 4.29 and the standard deviation of 1.14 , this is a rather small effect that may nevertheless give rise to discussions in the party meetings when it comes to nominating candidates. The estimated coefficients of the covariates suggest that incumbents obtained higher vote shares than newcomers which is in line with the findings by Lee (2001) and Lee et al. (2004). The first vote shares are also positively correlated with the proportional representation vote shares of the party with whom the candidates are affiliated. The estimate of almost unity indicates that the voters in general support the candidate nominated by their preferred party. We repeated the same exercise for candidates nominated by the three small parties. The results reported in column (4) of Table 2 suggest that the attractiveness of these candidates has a smaller and statistically less significant effect on their vote shares in direct elections.

As a robustness test we re-ran the regressions in Table 2 with a reduced sample that excludes Bavaria because a reviewer pointed out to us that CSU candidates regularly win the direct elections in Bavaria by very large margins. Since CSU candidates are rated as especially attractive, this correlation might drive our results. Our robustness test shows however that inferences do not change when excluding Bavaria.

One could also enter a second caveat. In the first four regressions reported in Table 2, the vote shares of the candidates running in the same electoral district are by definition correlated which is likely to result in an overestimation of the estimator precision. We therefore re-estimated these four models clustering standard errors at the district-period level and using the robust-cluster variance estimator. The standard error estimates of the attractiveness variable are reported in Table 3 (the numbering of the model specifications corresponds to numbering in Table 2). ${ }^{16}$ The differences in the estimated standard errors is minimal, the reason being that in more than one half of the 751 clusters no dependency occurs because these clusters contain only one elected candidate. $^{17}$

\footnotetext{
16 The entire regression outputs are reported in the appendix. Again, inferences do not change when excluding Bavaria.

17 In our full sample of 1169 candidates we have 420 clusters with one candidate, 255 with two, 65 with 3 , and 11 with 4 candidates.
} 
Table 3: OLS regressions with (period-district) cluster-robust standard errors. Dependent variable: vote share of sample candidates in direct elections.

\begin{tabular}{lcccc}
\hline & $\begin{array}{c}\text { All } \\
\text { parties } \\
(1)\end{array}$ & $\begin{array}{c}\text { All } \\
\text { parties } \\
(2)\end{array}$ & $\begin{array}{c}\text { Catch-all } \\
\text { parties } \\
(3)\end{array}$ & $\begin{array}{c}\text { Small } \\
\text { parties } \\
(4)\end{array}$ \\
\hline Attractiveness Score & 0.120 & $0.239^{* * *}$ & $0.325^{* * *}$ & $0.250^{*}$ \\
Cluster-Robust SE & $\mathbf{( 1 . 3 4 )}$ & $\mathbf{( 3 . 2 6 )}$ & $\mathbf{( 3 . 9 5 )}$ & $\mathbf{( 1 . 8 2 )}$ \\
Robust SE & $(1.32)$ & $(3.25)$ & $(3.96)$ & $(1.90)$
\end{tabular}

Notes: $t$ statistics in parentheses, ${ }^{*} p<0.10,{ }^{* *} p<0.05,{ }^{* * *} p<0.01$. This table shows the point estimate of the attractiveness score and standard errors. It refers to columns (1) to (4) in Table 2. The regressions include control variables. The full results are shown in Appendix $\mathrm{C}$ of the working paper version.

The beauty effect identified in the first four regressions reported in Table 2 may either derive from the fact that voters rather elect a physically attractive candidate than a less attractive one (intensive margin) or from more voters turning out when a candidate of their preferred political color is especially attractive (extensive margin). In column (5) of Table 2 we report the result of a regression in which we replace the dependent variable (vote share) with voter turnout. The attractiveness score of the winning candidates does not appear to be correlated with voter turnout. This result also applies when splitting the sample in catch-all and small party candidates and when using the difference in physical attractiveness between the two candidates who attained the largest vote shares (the detailed results are reported in Appendix $\mathrm{C}$ of the working paper version). We thus conclude that the beauty effect does indeed predict which candidate some voters vote for.

So far, we have not considered that, apart from the candidate's own physical attractiveness, the physical attractiveness of the competing candidates may also be correlated with the election result. We therefore report in Table 2, column (6), the results when regressing the difference in the attractiveness scores between the winner and the runner-up on the vote margin of the winner, i.e. the vote share of the directly elected MP. The capital letter D in column (6) indicates that the covariate is a first difference. As compared to the full sample, sample size is almost halved in this regression because we have only information on runner-ups who managed to get elected in one of the four elections covered in our study. The estimated effect is positive and statistically significant at the $1 \%$ level: a one scale-point difference in attractiveness between the directly elected MP and his closest competitor translates into a 0.358 percentage-point higher win margin of the elected MP. 


\subsection{Does beauty pay in closed-list, proportional representation elections?}

We conjecture that the physical attractiveness of the candidates running on closed lists in proportional representation elections is not associated with the election outcome. To test this hypothesis, we regress the parties' state-wide second vote share on the average attractiveness score of the prominent list candidates on the respective state list. Prominent candidates are defined as those who were elected. Focusing on the prominent candidates makes sense because the electorate only knows prominent candidates by face; the appearance of candidates who are placed at the back of the list is unlikely to leave any traces in the voters' memories. To capture the electorate's heterogeneity in political ideology across states, we included, apart from the state characteristics, the party dummies, and the period fixed effects, a variable that measures the difference between the respective party's second vote share in the state and at the federal level. The results are reported in Table 4.

\section{Table 4 about here}

The negative correlation between the average physical attractiveness of the prominent list candidates and the party's second vote share reported in column (1) disappears when we include the ideological orientation of the state electorate and the party dummies as covariates. The reason for the statistically significant negative correlation reported in column (1) is that the prominent candidates of small parties, i.e. the MPs of the parties with a low second vote share (FDP, Greens, The Left), are, as we have shown in section 3.2, physically more attractive than their peers from the catch-all parties CDU and SPD. Disregarding that these parties have smaller constituencies because they hold political minority views, biases the results and gives rise to this perhaps surprising result. In any event, considering candidates' party affiliation in specification (4) shows that the physical attractiveness of the candidates nominated in closed-list, proportional representation elections is not associated with the vote share and thus the distribution of seats.

We thus arrive at the conclusion that the beauty effect in general elections is only noticeable in first-past-the-post elections and not in closed-list, proportional elections. This asymmetric mode of operation of the beauty effect may give rise to strategic considerations in mixed election systems such as the one applied in German 
general elections. We now investigate whether such a gaming of the system can indeed be observed in Germany.

\subsection{Do parties condition the nomination of direct candidates on physical attractiveness?}

Only very few elected MPs did not run for direct election (54 out of the 1223 MPs in our sample); these few MPs were elected as list candidates in the proportional representation tier of the general election. Moreover, most MPs who were directly elected in their electoral district also ran on (top of) the list of their party in the proportional representation tier (1053 out of 1169 directly elected MPs). Only about $10 \%$ of the MPs were confident enough not to be put on the party list and to compete only as direct candidates (116 out of 1169 directly elected MPs - and most of these candidates ran in safe districts).

The best we can do is, therefore, to compare the physical attractiveness of MPs who ran for office only in electoral districts with those who also ran on the party list. Table 5 shows that the MPs of catch-all parties who only ran in electoral districts are, on average, physically more attractive (attractiveness score 4.44) than their peers from catch-all parties who ran on the state-wide party list as well (attractiveness score 4.25). The difference in attractiveness of 0.19 score points is statistically significant at the $10 \%$ level. This result does not carry over to the full sample that also includes MPs from the small parties. The difference in the attractiveness scores between all MPs who competed only in electoral districts and those who also ran on the party list is $4.43-$ $4.33=0.09$. This difference fails to be statistically significant. Restricting the sample to MPs from small parties, the difference turns out to be negative $(4.07-4.53=-0.46)$. Small party MPs who ran for office only in electoral districts thus appear to be on average physically less attractive than their peers who ran on the party list as well. This difference is, admittedly, far from being statistically significant. This result nevertheless lends support to the supposition that direct candidates of small parties are, in general, not nominated with the objective of getting elected. They are not supposed to campaign for themselves, because their chances are in any case marginal, but for the party, i.e. they advertise in their campaigns their parties' merits in the hope of thereby increasing the super important second vote share of these small parties. Since advertising ideas 
(and perhaps also denigrating the political opponent), does not necessarily require good looks but rather charisma and a rhetoric talent, it is not surprising that small party direct candidates often lack physical attractiveness.

Table 5: Two sample t-tests.

Difference in attractiveness scores: both direct and list vs. direct only candidates.

\begin{tabular}{lccccc}
\hline $\begin{array}{l}\text { Attractiveness } \\
\text { Score of: }\end{array}$ & $\begin{array}{c}\text { Both direct } \\
\text { and list }\end{array}$ & Direct only & Diff. & Test stat. & Obs. \\
\hline & $(1)$ & $(2)$ & $(3)$ & $(4)$ & $(5)$ \\
\hline all parties & 4.33 & 4.43 & -0.09 & -0.85 & 1169 \\
catch-all parties & 4.25 & 4.44 & $-0.19^{*}$ & 1.71 & 844 \\
small parties & 4.53 & 4.07 & 0.46 & 0.53 & 325
\end{tabular}

Notes: ${ }^{*} p<0.10,{ }^{* *} p<0.05,{ }^{* * *} p<0.01$. Columns (1) and (2) show the means of the attractiveness scores (as measured on a ten-point scale). Column (3) shows the difference between the means in columns (1) and (2). Column (4) shows the test statistic of a two-sample t-test testing whether the means in column (1) and (2) are equal. Column (5) shows the number of observations.

In principle, one could interpret the better looks of catch-all party MPs who ran only in direct elections to reflect electoral culling of the less attractive candidates. Since we have shown in section 4.1 that the beauty premium is rather small, this mechanism is, however, unlikely to drive the result. Moreover, the culling argument would also apply to the MPs who were elected directly but also ran on the party list. Our result is more likely to indicate that only very self-confident catch-all party candidates consent to run for direct election without hedging their risk by being placed on a favorable list place. Such confident candidates are often blessed with an especially pleasing appearance. An alternative hypothesis would be that parties nominate physically attractive candidates to run in contested districts in the hope of profiting from the halo effect of an attractive direct candidate and thereby obtaining a lager second vote share. We test this hypothesis in the next section. 


\subsection{Do parties nominate especially attractive candidates to run in fiercely}

\section{contested districts?}

In safe districts, elections are, by definition, not much of a contest because the candidate of the party that "owns" the district almost always wins. ${ }^{18}$ All other candidates are in the situation faced by small party candidates who have to compete against catch-all party candidates: whoever runs and whatever these candidates look like is unlikely to influence the outcome. We therefore expect that the nomination of candidates running in safe district elections is not influenced by the attractiveness of the available candidates. This argument implies, in particular, that the party that owns the safe district does not pay as much attention to the physical attractiveness of their candidate as they would in a contested district. The party may even let a rather unattractive candidate run, thereby saving a more attractive alternative candidate for a contested district where physical attractiveness really matters. Both lines of argument give rise to the hypothesis that parties that own safe districts nominate in these districts, on average, less attractive candidates than in contested districts.

The nomination game involves, of course, strategic interaction. If a party nominates in one of her safe districts a physically rather unattractive candidate, the closest contender, usually the candidate of the other catch-all party, may react by nominating an especially attractive candidate in the hope of closing the gap that originates from the ideological alignment of a large part of the electorate with the competing party. Anticipating this move, the party defending her safe district may react by nominating a candidate whose physical appearance does not (as much) jeopardize electoral success as the candidate considered in the first place. The outcome of the nomination game is thus not as straightforward as it might appear at a first glance. As so often, theoretical considerations do not supply clear hypotheses and we are left with an empirical question.

We use two types of labelling contested versus safe districts. The first label considers an electoral district to be safe for a party if this party has won the district in the previous election with a vote share difference exceeding 15 percentage points.

\footnotetext{
18 Enjoying supermajorities in safe districts has been shown to influence politicians' behavior (e. $\mathrm{g}$. Kauder and Potrafke 2016 and 2019).
} 
Otherwise the district is considered to be contested. The second label considers a district to be safe for a party if this party won the district in the previous three elections.

We examine whether competing in a safe CDU/CSU or a safe SPD district has an influence on the attractiveness of the nominated candidates. We thus distinguish between safe CDU/CSU districts, safe SPD districts, and contested districts. Our sample includes 605 districts for which we can observe the attractiveness of both the winner and the runner-up, i.e. districts in which also the runner-up became an MP, either via the party list or by being directly elected in another legislative period in our dataset. We regress the attractiveness score of the CDU/CSU (SPD) candidates on dummy variables assuming the value one for safe CDU/CSU (SPD) districts (contested districts being the reference category), the candidates' gender and age (logarithmized), and the attractiveness score of the opponent.

The results reported in the first two columns of Table 6 suggest that CDU/CSU candidates running in safe CDU/CSU districts were more attractive than CDU/CSU candidates running in contested districts. CDU/CSU candidates running in safe SPD districts did, however, not differ in attractiveness from CDU/CSU candidates running in contested districts. The attractiveness of the CDU/CSU candidates thus does not appear to correlate with the attractiveness of the competing SPD candidates. These results carry over to SPD candidates if district safety is defined as having won the district in the last three elections (column 3). When using the 15\%-margin in the preceding election to identify safe districts (column 4), SPD candidates running in safe SPD districts no longer differ in attractiveness from their comrades running in contested districts, but the SPD candidates running in safe CDU/CSU districts were significantly less attractive. Moreover, the attractiveness of the SPD candidates is in this specification positively correlated with the attractiveness of the CDU/CSU candidates. The size of the coefficient is however small and statistically significant only at the $10 \%$ level. 
Table 6: OLS regressions with robust standard errors.

Dependent variable: attractiveness score of party's direct candidates.

\begin{tabular}{|c|c|c|c|c|}
\hline & \multicolumn{2}{|c|}{$\mathrm{CDU} / \mathrm{CSU}$} & \multicolumn{2}{|c|}{ SPD } \\
\hline & (1) & (2) & (3) & (4) \\
\hline Safe District SPD (3 & 0.076 & & $0.291^{* *}$ & \\
\hline Periods) & $(0.52)$ & & $(2.19)$ & \\
\hline Safe District CDU/CSU & $0.382^{* * *}$ & & -0.105 & \\
\hline (3 Periods) & $(2.75)$ & & $(-0.69)$ & \\
\hline Safe District SPD & & -0.038 & & -0.049 \\
\hline (15 pp margin) & & $(-0.29)$ & & $(-0.38)$ \\
\hline Safe District CDU/CSU & & $0.358^{* * *}$ & & $-0.343^{* * *}$ \\
\hline (15 pp margin) & & $(3.03)$ & & $(-3.09)$ \\
\hline \multicolumn{5}{|l|}{ Controls } \\
\hline \multirow[t]{2}{*}{ Male Candidate } & $-0.328^{* * *}$ & $-0.352^{* * *}$ & $0.295^{* * *}$ & $0.056^{*}$ \\
\hline & $(-2.83)$ & $(-3.04)$ & $(3.53)$ & $(1.73)$ \\
\hline \multirow[t]{2}{*}{ Log Age } & $-2.168^{* * *}$ & $-2.171^{* * *}$ & $-2.064^{* * *}$ & $-2.082^{* * *}$ \\
\hline & $(-9.52)$ & $(-9.62)$ & $(-8.41)$ & $(-8.71)$ \\
\hline Attractiveness Score of & 0.012 & 0.028 & 0.048 & $0.056^{*}$ \\
\hline Opponent & $(0.30)$ & $(0.70)$ & $(1.45)$ & $(1.73)$ \\
\hline Constant & $12.807^{* * *}$ & $12.757^{* * *}$ & $11.878^{* * *}$ & $12.003^{* * *}$ \\
\hline & $(13.92)$ & $(14.04)$ & $(12.08)$ & $(12.49)$ \\
\hline Observations & 605 & 605 & 605 & 605 \\
\hline $\mathrm{R}^{2}$ & 0.177 & 0.180 & 0.160 & 0.168 \\
\hline
\end{tabular}

Notes: $t$ statistics in parentheses, ${ }^{*} p<0.10,{ }^{* *} p<0.05,{ }^{* * *} p<0.01$. Safe District (3 Periods) means that a party won the district in the previous three elections. Safe District (15 pp margin) means that the margin of victory in the previous election was at least 15 percentage points.

\subsection{Are physically attractive MPs more likely to vote against the party line?}

Studies that investigate dissension behavior in the German Bundestag by differentiating between directly elected MPs and list MPs include Stratmann (2006), Becher and Sieberer (2008), Sieberer (2010), Sieberer and Ohmura (2020). We contribute to this literature by exploring whether the physical attractiveness of MPs mediates their proclivity to dissent. To do so, we use data collected by Kauder et al. (2017) on roll-call votes in the period 2009-2013. The resulting sample documents the voting behavior of 621 MPs in 218 roll-call votes.

We used two kinds of dependent variables: the dissension rates of the individual MPs across the 218 roll-call votes and MP-specific dissension dummies for all 218 rollcall votes. Dissent is defined as not voting in line with the vast majority of the fellow party members. The results reported in Panel (a) of Table 7 suggest that the MPs' 
dissension ratio varies positively with their physical attractiveness (column 1 , the full regression output is reported in the appendix). This statistically significant effect turns out to derive from the behavior of the directly elected MPs (column 3). The dissension ratio of directly elected MPs increases by around 0.38 percentage points (around 0.11 standard deviations) when the attractiveness score increases by one point. The estimate reported in the second column indicates that physical attractiveness of list-MPs is not correlated with voting against the party line.

In Panel (b) of Table 7 we estimated marginal effects of attractiveness on dissent when using a dummy variable (dissent $=1$ ) for each MP and each roll-call vote. Again, we find that an MPs physical attractiveness only encourages dissension if the MP is directly elected. Physically attractive MPs elected via the party list are not more likely to dissent from the party line than their less attractive list-elected fellow party member.

Table 7

Panel a: OLS regressions with robust standard errors. Dependent Variable: dissension rate. MPs 2009-2013.

\begin{tabular}{lccc}
\hline & All MPs & List MPs & Direct MPs \\
\hline & $(1)$ & $(2)$ & $(3)$ \\
\hline Attractiveness Score & $0.258^{* *}$ & 0.155 & $0.385^{* *}$ \\
& $(1.97)$ & $(0.78)$ & $(2.19)$ \\
Controls & YES & YES & YES \\
\hline Observations & 621 & 322 & 299
\end{tabular}

Panel b: Bivariate probit regressions with (period-district) cluster-robust standard errors. Dependent variable: vote-specific dissension dummies. MPs 2009-2013. Marginal effects at the mean.

\begin{tabular}{lccc}
\hline & $(1)$ & $(2)$ & $(3)$ \\
\hline Attractiveness Score & $0.003^{* * *}$ & 0.002 & $0.004^{* * *}$ \\
& $(2.86)$ & $(1.31)$ & $(3.02)$ \\
Controls & YES & YES & YES \\
& & & 59276 \\
\hline Observations & 120951 & 61675 & \\
Notes: $t$ statistics in parentheses, ${ }^{*} p<0.10,{ }^{* *} p<0.05,{ }^{* * *} p<0.01$. The full results are shown in Appendix \\
C of the working paper version.
\end{tabular}

We also examined the conditional correlation between MPs' physical attractiveness and voting against the party line by the type of roll-call votes. Table 8 
reports the estimated marginal effects of the MP's attractiveness scores on their dissension behavior for different types of roll-call votes.

\section{Table 8 about here}

The results indicate that physical attractiveness is positively correlated with directly elected MPs voting against the party line for most of these types of issues. By using Google Trends, we identified the Top 10 roll-call votes over the period 2009-2013. The results in the first row suggest that the attractiveness score of directly elected MPs is positively correlated with voting against the party line in these top-10 roll-call votes (columns 5 and 6), but not for list MPs (columns 3 and 4). Overall, the positive correlation between physical attractiveness of directly elected MPs and dissension is statistically significant for domestic and European policies in general, for general foreign policies, and the three types of rescue packages. With one exception (domestic policies in general), physically attractive list MPs were not more likely to dissent from their respective party line. Physical attractiveness hence buys directly elected MPs some latitude to champion their own opinion or, more likely, the prevailing opinion in their constituencies if this opinion happens not to be in line with the party's position. The beauty effect on dissension is, however, admittedly rather small: an MP who is, on our ten-point attractiveness scale, one point more attractive than an otherwise comparable peer, is only about one percentage point more likely to dissent than this more party loyal peer.

\subsection{Sniff tests}

We submitted our results to rigorous robustness tests (Snyder and Zhou 2018). We used different filters to weed out insincere raters of attractiveness, the median instead of the average attractiveness scores of individual politicians, and different specifications of our empirical models. None of these tests indicated any particular sensitivity of our results.

In the baseline model, we excluded observations when raters assigned the same values to all rated portraits. We also excluded observations when raters assigned similar attractiveness scores to most portraits, when they answered by one or two standard deviations faster than the average rater, and when they did not use the upper half of 
the ten-point-scale. Inferences regarding the main effects of attractiveness on vote shares, party choices, and voting against the party line do not change. Some findings regarding differences in attractiveness across political ideologies and the nomination of more attractive candidates in the direct tier of the election do, however, lose the $10 \%$ statistical significance reported in Tables 1 and 5 . The same applies when the attractiveness scores are calculated as medians rather than as averages of the individual ratings.

Relaxing the vote margin requirement for safe districts to the ten- and fivepercent level does not change inferences regarding the beauty effect on candidate choice. Our models are furthermore robust to the introduction of state fixed effects and clustering standard errors at the district level.

\section{Limitations of our study}

Our study has limitations. The attractiveness scores may well correlate with candidates' individual features shown on the photos (clothing, jewelry etc.) that we do not include in our empirical model. We do not make attempts to control for individual features shown on the photos because there is a plethora of features one may consider. Raters' perceptions and candidates' party affiliation are likely to be correlated with the candidates' clothing. Clothing may well influence raters' perceptions (e.g. Hamermesh

et al. 2002, Oh et al. 2020) and clothing may vary across leftwing and rightwing politicians. Rightwing politicians seem to wear more often ties, suits and blouses than leftwing politicians. Other features such as beards, make-up and jewelry may also vary across leftwing and rightwing politicians (Licata and Méon 2016) - and they are also likely to be correlated with our attractiveness measure.

German raters might have arrived at different attractiveness scores than our American raters. To examine whether inferences would change based on attractiveness scores of German raters, we would need to use scores of German raters which, unfortunately, we do not have at hand. In any event, the literature quite agrees that physical attraction is not in the eye of the beholder; it is a universal trait. Asking German raters is therefore unlikely to make a difference. 
One may wish to consider sociodemographic and cultural characteristics of the raters and use attractiveness scores depending on whether raters were young or old, male or female, well-educated, party members, etc. Religion of the raters may also correlate with ratings. Muslim raters may well have different views of appropriate clothing (for example, of women who do not wear scarfs) than Christian raters. We do not, however, know the cultural background of the raters. We have information about the gender and age of the raters. The variation is, however, small. Some photos were rated only by old men. We prefer to not disentangle attractiveness scores depending on raters' gender and age.

Standardized pictures of all candidates - not just the candidates who won the races - would be nice to be considered. It is conceivable that the attractiveness of defeated candidates correlates with electoral success of the candidates that won the election. There are no standardized pictures of all candidates available.

We would love to measure the candidates' competence and cognitive skills and the voters' preferences regarding politicians' physical attractiveness and competence. Of course, we cannot rule out that differences in the candidates' competence and cognitive skills are related to the differences in attractiveness. It is quite possible that rightwing politicians win elections because they are competent; if they are attractive as well, confounding is possible. Leftwing voters may care less about beauty of politicians than rightwing voters and vote for ugly candidates whom they consider to be very clever. Having data about candidates' competence and cognitive skills and voters' preferences regarding politicians' physical attractiveness and competence would help to disentangle the effect of physical attractiveness. Unfortunately, we do not have such data.

\section{Conclusions}

It is well known that physically attractive candidates have an advantage in elections to public offices. We ask three questions relating to this "beauty premium": to what extent do commonly used election systems mediate the beauty premium, do political parties strategically exploit the beauty premium when deciding which candidates to nominate, and do elected MPs use their beauty premium to reap some independence from their party? To answer these questions, we use data from four German federal elections held 
between 2002 and 2013. The German election system is eminently suitable for our purposes because it is a mixed system that combines two extreme forms of elections: plurality election and proportional representation. We are thus able to compare the working of these two election systems in one round of election by the same electorate.

Our results are as follows. In line with related studies, we find non-marginal, statistically significant beauty premiums in the direct, first-past-the-post election tier of the elections. In the closed-list, proportional representation tier, however, the physical attractiveness of the list candidates has no statistically significant effect on the election outcome. The design of the election system thus determines to a large extent how physical attractiveness of political candidates is mediated.

The two election tiers' dissimilar modes of mediating physical attractiveness provide the political parties, in principle, with ample scope for strategic manipulations. Since the physical appearance of the list candidates has no influence on the party's allimportant second vote share, it would, for example, be a waste to put a physically attractive candidate on a top list place if the party thereby foregoes the opportunity to have a valuable party member elected who, because of his unappealing appearance, has hardly a chance of being elected directly. Moreover, when it comes to nominating candidates for direct election in the electoral districts, it is not farfetched to assume that parties might assign physically attractive candidates to contested districts, whereas safe districts are used to accommodate less attractive candidates. It turns out that the empirical evidence does not lend strong support to these apprehensions. To be sure, we find some evidence that catch-all party candidates who run only for direct election are on average physically more attractive than catch-all party candidates who also run on the list and that the social democrats do not waste their most attractive candidates in districts that are considered safe for the conservative party; but it turns out that candidates nominated to defend safe districts are physically not less, but more attractive than candidates who are nominated to run in contested districts or in districts in which they are underdogs. The reason why German political parties do not distribute their "beauty capital" in election campaigns as strategically as their financial capital is likely to be a consequence of the decentralized organization of German political parties. It is the prerogative of the local party caucus to nominate the candidates for their election district, implying that the state party's leverage is very limited in this respect. Apart from the design of the election system, this federalist structure constitutes a second 
institutional provision that helps to neutralize the influence of the beauty premium and the attendant possibilities of gaming elections. A complementary reason for why parties do not strategically use candidates' physical attractiveness may be envy of same-sex individuals (Smith et al. 1999): for example, attractive female candidates may enjoy electoral support by males but lose support from jealous female voters. When male voters are encouraged to the same extent as female voters are discouraged by attractive female candidates, candidates' attractiveness does overall not matter.

The last question that we raised is whether the physical attractiveness of elected MPs has an influence on how they function on their job, in particular, whether physically attractive MPs dissent more often from their respective party lines than their less attractive peers do. We can answer this question in the affirmative. This result is, however, driven by directly elected MPs; the physical attractiveness of MPs elected via the proportional representation tier has no statistically significant influence on their party discipline. This result complements findings indicating that candidate-centered electoral systems and decentralized candidate selection rules allows parliamentarians to enjoy a proper measure of mainstream fame to deviation from the party line and stick to their own political principles or, more likely, to their own campaign promises (Hix 2004). 
Tables in text 
Table 2: OLS regressions with robust standard errors.

Dependent variable: vote share of full sample candidates in direct elections.

\begin{tabular}{|c|c|c|c|c|c|c|}
\hline & $\begin{array}{c}\text { All } \\
\text { parties }\end{array}$ & $\begin{array}{c}\text { All } \\
\text { parties } \\
(2)\end{array}$ & $\begin{array}{l}\text { Catch- } \\
\text { all } \\
\text { parties } \\
(3)\end{array}$ & $\begin{array}{c}\text { Small } \\
\text { parties } \\
(4)\end{array}$ & Turnout & $\begin{array}{c}\text { Vote } \\
\text { share } \\
\text { difference } \\
(6)\end{array}$ \\
\hline Attractiveness Score & $\begin{array}{l}0.120 \\
(1.32)\end{array}$ & $\begin{array}{l}0.239^{* * *} \\
(3.25)\end{array}$ & $\begin{array}{c}0.325^{* * *} \\
(3.96)\end{array}$ & $\begin{array}{l}0.250^{*} \\
(1.90)\end{array}$ & $\begin{array}{l}0.002 \\
(0.02)\end{array}$ & $\begin{array}{c}\text { D } 0.358^{* * *} \\
(3.59)\end{array}$ \\
\hline \multicolumn{7}{|l|}{ Candidate controls } \\
\hline Log Age & $\begin{array}{c}2.688^{* * *} \\
(4.97)\end{array}$ & $\begin{array}{c}1.269^{* * *} \\
(2.81)\end{array}$ & $\begin{array}{l}0.404 \\
(0.83)\end{array}$ & $\begin{array}{c}2.426^{* * *} \\
(3.03)\end{array}$ & $\begin{array}{l}0.527 \\
(1.06)\end{array}$ & $\begin{array}{c}\text { D } 0.716 \\
(1.30)\end{array}$ \\
\hline $\mathrm{PhD}$ & $\begin{array}{l}0.292 \\
(1.10)\end{array}$ & $\begin{array}{l}0.565^{* * *} \\
(2.60)\end{array}$ & $\begin{array}{l}0.418^{*} \\
(1.72)\end{array}$ & $\begin{array}{l}0.145 \\
(0.39)\end{array}$ & $\begin{array}{l}0.115 \\
(0.47)\end{array}$ & $\begin{array}{l}0.314 \\
(0.98)\end{array}$ \\
\hline Male Candidate & $\begin{array}{l}-0.218 \\
(-1.06)\end{array}$ & $\begin{array}{l}0.266 \\
(1.57)\end{array}$ & $\begin{array}{l}0.104 \\
(0.57)\end{array}$ & $\begin{array}{c}0.646^{* *} \\
(2.19)\end{array}$ & $\begin{array}{l}0.291 \\
(1.47)\end{array}$ & $\begin{array}{l}0.096 \\
(0.28)\end{array}$ \\
\hline Incumbency Status & $\begin{array}{c}1.754^{* * *} \\
(7.12)\end{array}$ & $\begin{array}{l}2.075^{* * *} \\
(10.00)\end{array}$ & $\begin{array}{l}1.859^{* * *} \\
(9.37)\end{array}$ & $\begin{array}{l}5.812^{* * *} \\
(3.44)\end{array}$ & $\begin{array}{l}0.027 \\
(0.11)\end{array}$ & $\begin{array}{c}1.370^{* * *} \\
(4.02)\end{array}$ \\
\hline PhD Runnerup & & & & & & $\begin{array}{l}-0.240 \\
(-0.70)\end{array}$ \\
\hline Male Runnerup & & & & & & $\begin{array}{l}-0.350 \\
(-1.32)\end{array}$ \\
\hline $\begin{array}{l}\text { Incumbency Status } \\
\text { Runnerup }\end{array}$ & & & & & & $\begin{array}{l}-2.144^{* * *} \\
(-3.92)\end{array}$ \\
\hline \multicolumn{7}{|l|}{ District controls } \\
\hline Turnout in District & $\begin{array}{l}-0.023 \\
(-0.72)\end{array}$ & $\begin{array}{l}0.013 \\
(0.46)\end{array}$ & $\begin{array}{l}0.086^{* * *} \\
(2.91)\end{array}$ & $\begin{array}{l}-0.083 \\
(-1.46)\end{array}$ & & $\begin{array}{c}-0.208^{* * *} \\
(-4.29)\end{array}$ \\
\hline Unemployment Rate & $\begin{array}{c}-0.098^{* * *} \\
(-3.13)\end{array}$ & $\begin{array}{c}-0.133^{* * *} \\
(-4.83)\end{array}$ & $\begin{array}{c}-0.168^{* * *} \\
(-5.99)\end{array}$ & $\begin{array}{l}0.052 \\
(0.99)\end{array}$ & $\begin{array}{c}-0.531^{* * *} \\
(-20.51)\end{array}$ & $\begin{array}{c}-0.161^{* * *} \\
(-2.93)\end{array}$ \\
\hline Male Population (Percent) & $\begin{array}{l}3.668 \\
(0.76)\end{array}$ & $\begin{array}{l}1.142 \\
(0.21)\end{array}$ & $\begin{array}{l}0.639 \\
(0.11)\end{array}$ & $\begin{array}{l}35.351 \\
(1.31)\end{array}$ & $\begin{array}{c}- \\
17.599^{* * *} \\
(-3.55)\end{array}$ & $\begin{array}{c}-14.074^{* * *} \\
(-4.31)\end{array}$ \\
\hline District Size $\left(1000 \mathrm{~km}^{2}\right)$ & $\begin{array}{l}-0.283^{* *} \\
(-2.04)\end{array}$ & $\begin{array}{l}-0.216 \\
(-1.57)\end{array}$ & $\begin{array}{c}-0.489^{* * *} \\
(-3.74)\end{array}$ & $\begin{array}{l}0.505^{* *} \\
(2.28)\end{array}$ & $\begin{array}{l}-1.012^{* * *} \\
(-10.19)\end{array}$ & $\begin{array}{l}-0.304^{*} \\
(-1.66)\end{array}$ \\
\hline $\begin{array}{l}\text { Population Density } \\
\left(1000 / \mathrm{km}^{2}\right)\end{array}$ & $\begin{array}{l}0.137 \\
(0.90)\end{array}$ & $\begin{array}{l}0.106 \\
(0.64)\end{array}$ & $\begin{array}{l}0.052 \\
(0.35)\end{array}$ & $\begin{array}{l}0.121 \\
(0.49)\end{array}$ & $\begin{array}{l}0.082 \\
(1.01)\end{array}$ & $\begin{array}{l}0.095 \\
(0.54)\end{array}$ \\
\hline \multicolumn{7}{|l|}{ Party controls } \\
\hline Party's Second vote share & $\begin{array}{l}1.121^{* * *} \\
(120.17)\end{array}$ & $\begin{array}{l}0.988^{* * *} \\
(77.39)\end{array}$ & $\begin{array}{l}0.994^{* * *} \\
(73.69)\end{array}$ & $\begin{array}{l}0.952^{* * *} \\
(34.08)\end{array}$ & $\begin{array}{l}-0.001 \\
(-0.10)\end{array}$ & $\begin{array}{l}\mathrm{D} 0.938^{* * *} \\
\quad(68.06)\end{array}$ \\
\hline SPD & & $\begin{array}{l}0.414^{* *} \\
(2.16)\end{array}$ & $\begin{array}{c}0.417^{* *} \\
(2.27)\end{array}$ & & $\begin{array}{l}0.044 \\
(0.19)\end{array}$ & $\begin{array}{l}0.602^{*} \\
(1.68)\end{array}$ \\
\hline Greens & & $\begin{array}{c}-4.697^{* * *} \\
(-9.70)\end{array}$ & & $\begin{array}{c}3.190^{* * *} \\
(7.36)\end{array}$ & $\begin{array}{l}0.921^{*} \\
(1.88)\end{array}$ & $\begin{array}{c}23.285^{* * *} \\
(11.60)\end{array}$ \\
\hline The Left & & $\begin{array}{c}-2.938^{* * *} \\
(-6.99)\end{array}$ & & $\begin{array}{c}3.602^{* * *} \\
(8.72)\end{array}$ & $\begin{array}{l}-0.341 \\
(-0.72)\end{array}$ & $\begin{array}{l}0.109 \\
(0.06)\end{array}$ \\
\hline FDP & & $\begin{array}{l}-8.283^{* * *} \\
(-17.20)\end{array}$ & & & $\begin{array}{l}0.761 \\
(1.58\end{array}$ & \\
\hline Fixed period dummies & YES & YES & YES & YES & YES & YES \\
\hline Constant & $\begin{array}{c}-12.81^{* * *} \\
(-2.89)\end{array}$ & $\begin{array}{l}-3.944 \\
(-0.90)\end{array}$ & $\begin{array}{l}-6.073 \\
(-1.31)\end{array}$ & $\begin{array}{c}-26.279 \\
(-1.57)\end{array}$ & $\begin{array}{c}92.490^{* * *} \\
(27.78)\end{array}$ & $\begin{array}{c}25.787^{* * *} \\
(5.35)\end{array}$ \\
\hline Observations & 1169 & 1169 & 844 & 325 & 1169 & 622 \\
\hline $\mathrm{R}^{2}$ & 0.960 & 0.974 & 0.946 & 0.887 & 0.635 & 0.920 \\
\hline
\end{tabular}

Notes: $t$ statistics in parentheses, ${ }^{*} p<0.10,{ }^{* *} p<0.05,{ }^{* * *} p<0.01$. The dependent variable is measured in percent. Runnerup refers to the second placed candidate with respect to the achieved vote share. District controls are measured at the year of the election. 
Table 4: OLS regressions with robust standard errors.

Dependent variable: parties' state-wide second vote share.

\begin{tabular}{|c|c|c|c|c|}
\hline & $(1)$ & $(2)$ & (3) & (4) \\
\hline Average Attractiveness & $-3.891^{* * *}$ & $-0.954^{*}$ & 0.062 & 0.056 \\
\hline Score & $(-4.03)$ & $(-1.74)$ & $(0.15)$ & $(0.14)$ \\
\hline \multicolumn{5}{|l|}{ Political controls } \\
\hline \multirow[t]{2}{*}{$\overline{\text { Ideol. orientation State }}$} & & & $0.806^{* * *}$ & $0.805^{* * *}$ \\
\hline & & & $(14.80)$ & $(14.57)$ \\
\hline \multirow[t]{2}{*}{ Turnout in State } & & & -0.018 & -0.031 \\
\hline & & & $(-0.18)$ & $(-0.18)$ \\
\hline \multicolumn{5}{|l|}{ District controls } \\
\hline \multirow[t]{2}{*}{ Unemployment Rate } & & -0.046 & & -0.010 \\
\hline & & $(-0.49)$ & & $(-0.08)$ \\
\hline \multirow[t]{2}{*}{ Male Population (Percent) } & & -213.808 & & -22.279 \\
\hline & & $(-1.32)$ & & $(-0.17)$ \\
\hline \multirow[t]{2}{*}{ State Size $\left(1000 \mathrm{~km}^{2}\right)$} & & 0.003 & & -0.001 \\
\hline & & $(0.07)$ & & $(-0.05)$ \\
\hline \multirow{2}{*}{$\begin{array}{l}\text { Population Density } \\
\left(1000 / \mathrm{km}^{2}\right)\end{array}$} & & -0.190 & & -0.007 \\
\hline & & $(-0.41)$ & & $(-0.02)$ \\
\hline \multicolumn{5}{|l|}{ Party dummies } \\
\hline \multirow[t]{2}{*}{ SPD } & & $-2.967^{* *}$ & $-3.865^{* * *}$ & $-3.864^{* * *}$ \\
\hline & & $(-2.02)$ & $(-3.31)$ & $(-3.28)$ \\
\hline \multirow[t]{2}{*}{ Greens } & & $-24.666^{* * *}$ & $-25.293^{* * *}$ & $-25.291^{* * *}$ \\
\hline & & $(-23.02)$ & $(-33.38)$ & $(-33.10)$ \\
\hline \multirow[t]{2}{*}{ The Left } & & $-19.495^{* * *}$ & $-7.135^{* * *}$ & $-7.138^{* * *}$ \\
\hline & & $(-11.69)$ & $(-5.54)$ & $(-5.50)$ \\
\hline \multirow[t]{2}{*}{ FDP } & & $-23.665^{* * *}$ & $-22.639^{* * *}$ & $-22.632^{* * *}$ \\
\hline & & $(-20.94)$ & $(-25.38)$ & $(-25.16)$ \\
\hline Fixed period dummies & NO & YES & YES & YES \\
\hline \multirow[t]{2}{*}{ Constant } & $37.331^{* * *}$ & $143.096^{*}$ & $33.725^{* * *}$ & 45.761 \\
\hline & $(8.45)$ & $(1.80)$ & $(4.45)$ & $(0.66)$ \\
\hline Observations & 283 & 283 & 283 & 283 \\
\hline $\mathrm{R}^{2}$ & 0.041 & 0.712 & 0.850 & 0.850 \\
\hline
\end{tabular}

Notes: $t$ statistics in parentheses, ${ }^{*} p<0.10,{ }^{* *} p<0.05,{ }^{* * *} p<0.01$. The dependent variable is measured in percent. District controls are measured at the year of the election. Ideological orientation of the state measures the difference between the party's second vote share at the state and at the federal level. 
Table 8: Bivariate probit regressions with (period-district) cluster-robust standard errors. Dependent variable: vote-specific dissension dummies. MPs 2009-2013.

Marginal effects of the attractiveness score at the mean.

\begin{tabular}{|c|c|c|c|c|c|c|}
\hline \multirow[t]{2}{*}{ Type of roll-call votes } & \multicolumn{2}{|c|}{ All MPs } & \multicolumn{2}{|c|}{ List MPs } & \multicolumn{2}{|c|}{ Direct MPs } \\
\hline & $\begin{array}{l}\text { without } \\
\text { controls } \\
\text { (1) }\end{array}$ & $\begin{array}{c}\text { with } \\
\text { controls } \\
\text { (2) }\end{array}$ & $\begin{array}{l}\text { without } \\
\text { controls } \\
\text { (3) }\end{array}$ & $\begin{array}{c}\text { with } \\
\text { controls } \\
(4)\end{array}$ & $\begin{array}{l}\text { without } \\
\text { controls } \\
\text { (5) }\end{array}$ & $\begin{array}{c}\text { with } \\
\text { controls } \\
(6)\end{array}$ \\
\hline Top ten roll-call votes & $\begin{array}{l}0.004 \\
(1.46)\end{array}$ & $\begin{array}{l}0.007^{* *} \\
(2.05)\end{array}$ & $\begin{array}{l}0.001 \\
(0.28)\end{array}$ & $\begin{array}{l}0.006 \\
(1.10)\end{array}$ & $\begin{array}{l}0.008^{*} \\
(1.92)\end{array}$ & $\begin{array}{l}0.009^{*} \\
(1.96)\end{array}$ \\
\hline Military actions & $\begin{array}{l}0.003 \\
(0.71)\end{array}$ & $\begin{array}{l}0.003 \\
(1.14)\end{array}$ & $\begin{array}{l}-0.002 \\
(-0.33)\end{array}$ & $\begin{array}{l}0.001 \\
(0.15)\end{array}$ & $\begin{array}{l}0.005 \\
(0.91)\end{array}$ & $\begin{array}{l}0.004 \\
(1.52)\end{array}$ \\
\hline $\begin{array}{l}\text { Domestic policy } \\
\text { during the financial } \\
\text { and economic crisis }\end{array}$ & $\begin{array}{l}-0.001^{*} \\
(-1.70)\end{array}$ & $\begin{array}{l}-0.000 \\
(-0.64)\end{array}$ & $\begin{array}{l}-0.001 \\
(-1.36)\end{array}$ & $\begin{array}{l}-0.001^{*} \\
(-1.66)\end{array}$ & $\begin{array}{l}-0.000 \\
(-0.26)\end{array}$ & $\begin{array}{l}0.001 \\
(0.96)\end{array}$ \\
\hline $\begin{array}{l}\text { Domestic policy in } \\
\text { general }\end{array}$ & $\begin{array}{l}0.001^{*} \\
(1.65)\end{array}$ & $\begin{array}{l}0.002^{* * *} \\
(3.65)\end{array}$ & $\begin{array}{l}0.001 \\
(0.58)\end{array}$ & $\begin{array}{l}0.003^{* * *} \\
(2.68)\end{array}$ & $\begin{array}{l}0.001 \\
(1.24)\end{array}$ & $\begin{array}{c}0.002^{* * *} \\
(2.60)\end{array}$ \\
\hline Energy topics & $\begin{array}{l}-0.000 \\
(-0.13)\end{array}$ & $\begin{array}{l}0.001 \\
(0.65)\end{array}$ & $\begin{array}{l}0.000 \\
(0.10)\end{array}$ & $\begin{array}{l}0.000 \\
(0.55)\end{array}$ & $\begin{array}{l}-0.000 \\
(-0.04)\end{array}$ & $\begin{array}{l}0.001 \\
(0.42)\end{array}$ \\
\hline $\begin{array}{l}\text { European politics in } \\
\text { general }\end{array}$ & $\begin{array}{l}0.003 \\
(1.29)\end{array}$ & $\begin{array}{l}0.007^{* *} \\
(2.14)\end{array}$ & $\begin{array}{l}-0.000 \\
(-0.01)\end{array}$ & $\begin{array}{l}0.005 \\
(0.97)\end{array}$ & $\begin{array}{l}0.007^{* *} \\
(2.00)\end{array}$ & $\begin{array}{l}0.009^{* *} \\
(2.42)\end{array}$ \\
\hline General foreign policy & $\begin{array}{l}0.001 \\
(1.28)\end{array}$ & $\begin{array}{l}0.002^{*} \\
(1.85)\end{array}$ & $\begin{array}{l}-0.000 \\
(-0.26)\end{array}$ & $\begin{array}{l}0.000 \\
(0.41)\end{array}$ & $\begin{array}{l}0.003^{* *} \\
(2.09)\end{array}$ & $\begin{array}{l}0.004^{* *} \\
(2.37)\end{array}$ \\
\hline $\begin{array}{l}\text { European rescue } \\
\text { packages }\end{array}$ & $\begin{array}{l}0.004 \\
(1.33)\end{array}$ & $\begin{array}{l}0.009^{* *} \\
(2.14)\end{array}$ & $\begin{array}{l}0.000 \\
(0.04)\end{array}$ & $\begin{array}{l}0.007 \\
(1.03)\end{array}$ & $\begin{array}{l}0.009^{* *} \\
(2.00)\end{array}$ & $\begin{array}{l}0.011^{* *} \\
(2.33)\end{array}$ \\
\hline $\begin{array}{l}\text { Particular Greek } \\
\text { rescue packages I }\end{array}$ & $\begin{array}{l}0.001 \\
(0.50)\end{array}$ & $\begin{array}{l}0.004^{*} \\
(1.81)\end{array}$ & $\begin{array}{l}-0.003 \\
(-1.36)\end{array}$ & $\begin{array}{l}0.001 \\
(0.42)\end{array}$ & $\begin{array}{l}0.005^{* *} \\
(2.09)\end{array}$ & $\begin{array}{l}0.006^{* *} \\
(2.55)\end{array}$ \\
\hline $\begin{array}{l}\text { Particular Greek } \\
\text { rescue packages II }\end{array}$ & $\begin{array}{l}0.002 \\
(0.25)\end{array}$ & $\begin{array}{l}0.007 \\
(0.94)\end{array}$ & $\begin{array}{l}-0.012 \\
(-1.48)\end{array}$ & $\begin{array}{l}-0.002 \\
(-0.21)\end{array}$ & $\begin{array}{l}0.017^{* *} \\
(1.98)\end{array}$ & $\begin{array}{l}0.014^{*} \\
(1.70)\end{array}$ \\
\hline
\end{tabular}

Notes: $z$ statistics in parentheses, ${ }^{*} p<0.10,{ }^{* *} p<0.05,{ }^{* * *} p<0.01$. The sample documents the voting behavior of 621 MPs in 218 roll-call votes. Top 10 roll-call votes were identified using Google Trends, the other roll-call votes are manually categorized. The dependent variable for all models is a dissension dummy which indicates whether a MP did not vote in line with the majority of the fellow party members in a specific roll-call vote. The coefficients shown here are marginal effects of the attractiveness score at the mean. The marginal effects in columns (1), (3) and (5) refer to the attractiveness score in a model without controls. The marginal effects in columns (2), (4) and (6) were obtained from a model with controls for the MP's logarithmized age, gender and $\mathrm{PhD}$ title; the MP's average years in parliament, absence rate, speeches and oral contributions within the parliamentary term; whether the MP holds a function in the party, is a state secretary or minister during the year in which the roll-call vote was taken; whether the MP comes from a safe district which the MP's party has won in the previous three elections and whether the MP's party is part of the government coalition. The point estimates are reported in Appendix $\mathrm{C}$ of the working paper version. 
Appendix A: The survey

\section{Survey: Page 1 / Instructions}

In the following survey you are going to see black and white photos of political candidates. You will be asked to rate the attractiveness of the person in comparison to people in general on a 10point scale.

\section{Survey: Page 2 / Rating}
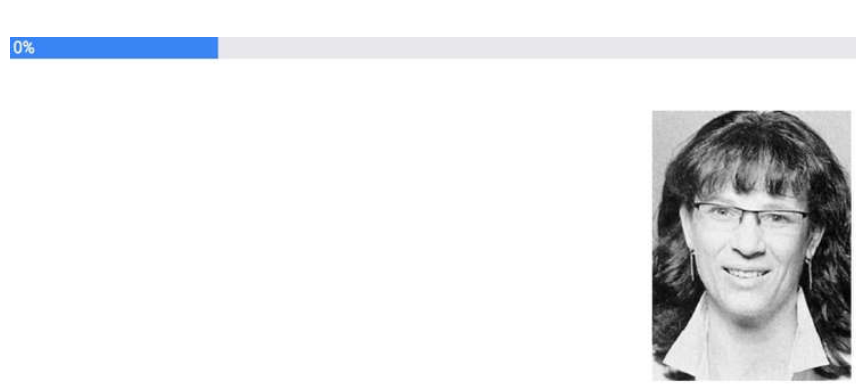

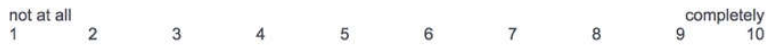

How attractive do you find this candidate compared to people in general? 
Appendix B: Example ballot

Example ballot for the 2013 German federal elections

\section{Stimmzettel}

für die Wahl zum Deutschen Bundestag

im Wahlkreis 11 Lübeck

am 22. September 2013

\section{Sie haben 2 Stimmen}
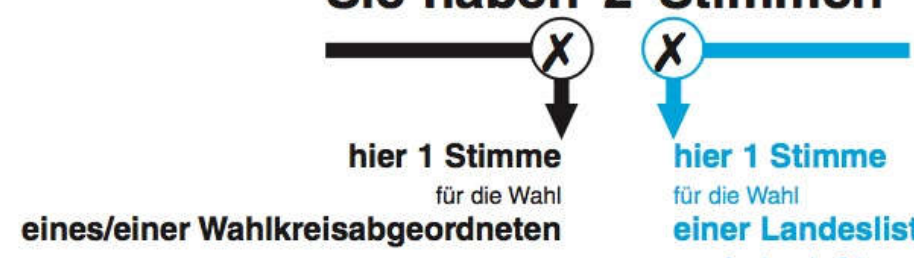

für die Wahl

einer Landesliste (Partei)

- maßgebende Stimme für die Verteilung der

Sitze insgesamt auf die einzelnen Parteien -

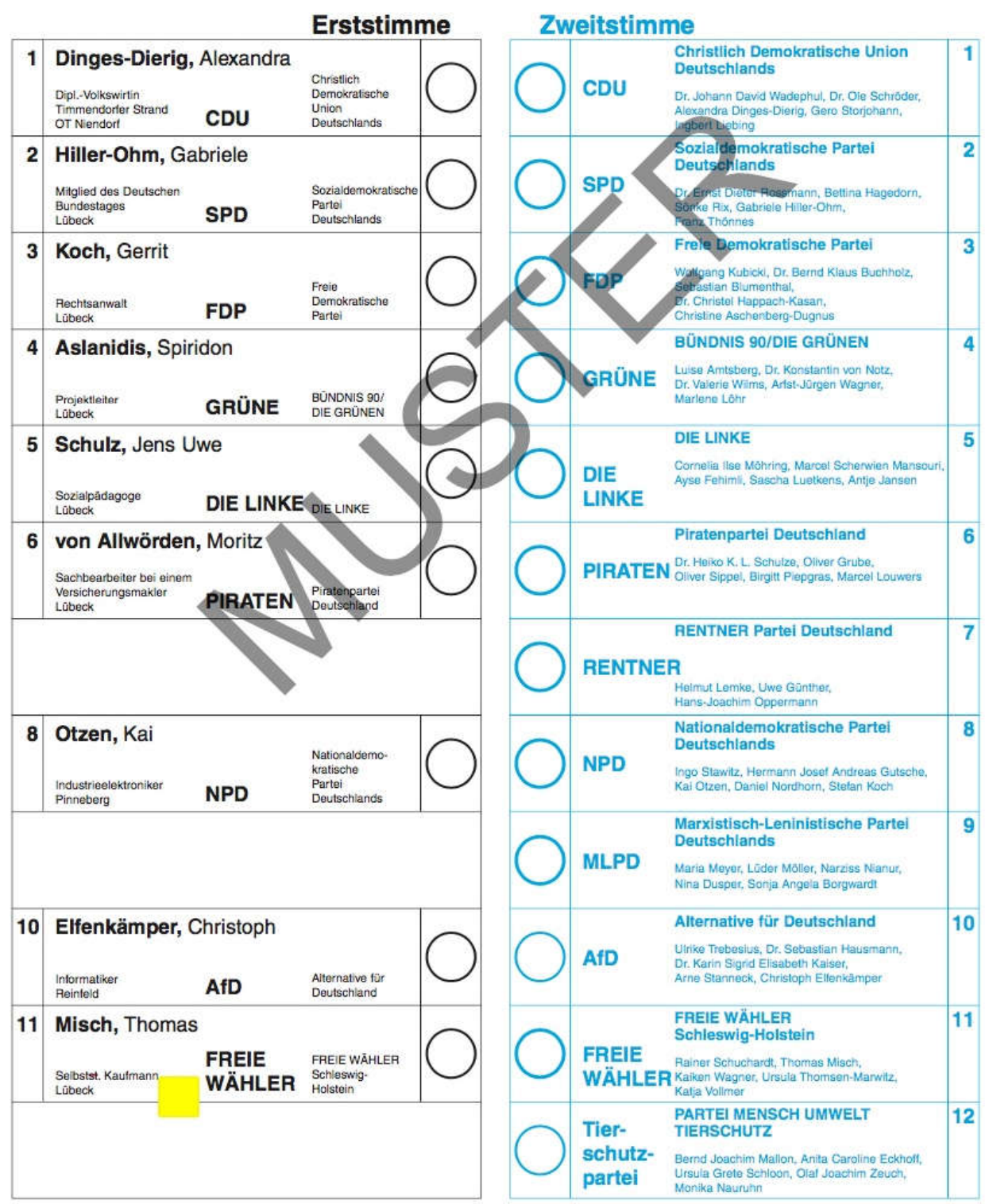

Source: Stadt Lübeck; http://www.luebeck.de (accessed: 15.03.2017) 
Appendix C: Tables that will be published only in the appendix of the working paper version 
re Table 2, column 5: OLS regressions with robust standard errors.

Dependent variable: voter turnout in electoral district.

\begin{tabular}{|c|c|c|c|}
\hline & $\begin{array}{c}\text { Catch-all parties } \\
(1)\end{array}$ & $\begin{array}{c}\text { Small parties } \\
(2) \\
\end{array}$ & $\begin{array}{c}\text { All parties } \\
\text { (differences) } \\
\text { (3) }\end{array}$ \\
\hline Attractiveness Score & $\begin{array}{l}-0.037 \\
(-0.36)\end{array}$ & $\begin{array}{l}-0.002 \\
(-0.01)\end{array}$ & $\begin{array}{c}\mathrm{D}-0.004 \\
(-0.06)\end{array}$ \\
\hline \multicolumn{4}{|l|}{ Candidate controls } \\
\hline Log Age & $\begin{array}{l}0.374 \\
(0.62)\end{array}$ & $\begin{array}{l}0.477 \\
(0.52)\end{array}$ & $\begin{array}{c}\text { D }-0.944^{* *} \\
(-2.01)\end{array}$ \\
\hline $\mathrm{PhD}$ & $\begin{array}{l}0.317 \\
(1.10)\end{array}$ & $\begin{array}{l}-0.289 \\
(-0.68)\end{array}$ & $\begin{array}{l}-0.078 \\
(-0.32)\end{array}$ \\
\hline Male Candidate & $\begin{array}{l}0.279 \\
(1.21)\end{array}$ & $\begin{array}{l}0.367 \\
(0.97)\end{array}$ & $\begin{array}{l}-0.078 \\
(-0.32)\end{array}$ \\
\hline Incumbency Status & $\begin{array}{l}0.110 \\
(0.42)\end{array}$ & $\begin{array}{l}-2.211^{*} \\
(-1.68)\end{array}$ & $\begin{array}{l}0.386 \\
(1.37)\end{array}$ \\
\hline PhD Runnerup & & & $\begin{array}{l}0.336 \\
(1.02)\end{array}$ \\
\hline Male Runnerup & & & $\begin{array}{l}0.421^{*} \\
(1.81)\end{array}$ \\
\hline Incumbency Status Runnerup & & & $\begin{array}{l}0.022 \\
(0.04)\end{array}$ \\
\hline First vote Share & & & $\begin{array}{c}\text { D }-0.153^{* * *} \\
(-4.49)\end{array}$ \\
\hline \multicolumn{4}{|l|}{ District controls } \\
\hline Unemployment Rate & $\begin{array}{c}-0.511^{* * *} \\
(-16.57)\end{array}$ & $\begin{array}{c}-0.597^{* * *} \\
(-11.61)\end{array}$ & $\begin{array}{c}-0.587^{* * *} \\
(-16.57)\end{array}$ \\
\hline Male Population (Percent) & $\begin{array}{c}-14.325^{* * *} \\
(-4.20)\end{array}$ & $\begin{array}{c}-112.015^{* * *} \\
(-3.90)\end{array}$ & $\begin{array}{c}-15.840^{* * * *} \\
(-2.78)\end{array}$ \\
\hline District Size (in $1000 \mathrm{~km}^{2}$ ) & $\begin{array}{c}-0.981^{* * *} \\
(-8.27)\end{array}$ & $\begin{array}{c}-0.916^{* * * *} \\
(-4.14)\end{array}$ & $\begin{array}{c}-0.506^{* * *} \\
(-3.12)\end{array}$ \\
\hline Population Density (in $1000 / \mathrm{km}^{2}$ ) & $\begin{array}{l}-0.044 \\
(-0.38)\end{array}$ & $\begin{array}{l}0.312^{* * *} \\
(2.55)\end{array}$ & $\begin{array}{l}0.056 \\
(0.35)\end{array}$ \\
\hline \multicolumn{4}{|l|}{ Party controls } \\
\hline$\overline{\text { Party's Second vote Share }}$ & $\begin{array}{l}-0.003 \\
(-0.17)\end{array}$ & $\begin{array}{l}0.022 \\
(0.64)\end{array}$ & $\begin{array}{c}\text { D } 0.097^{* * *} \\
(2.78)\end{array}$ \\
\hline SPD & $\begin{array}{l}0.040 \\
(0.17)\end{array}$ & & $\begin{array}{l}0.507^{*} \\
(1.80)\end{array}$ \\
\hline Greens & & $\begin{array}{l}-0.223 \\
(-0.47)\end{array}$ & $\begin{array}{c}8.461^{* * *} \\
(4.24)\end{array}$ \\
\hline The Left & & $\begin{array}{l}-1.041^{*} \\
(-1.75)\end{array}$ & $\begin{array}{l}-1.845 \\
(-1.32)\end{array}$ \\
\hline Fixed period dummies & YES & YES & YES \\
\hline Constant & $\begin{array}{c}91.526^{* * *} \\
(27.29)\end{array}$ & $\begin{array}{c}139.522^{* * *} \\
(9.48)\end{array}$ & $\begin{array}{c}72.320^{* * *} \\
(68.41)\end{array}$ \\
\hline Observations & 844 & 325 & 622 \\
\hline $\mathrm{R}^{2}$ & 0.627 & 0.683 & 0.746 \\
\hline
\end{tabular}

Notes: $t$ statistics in parentheses, ${ }^{*} p<0.10,{ }^{* *} p<0.05,{ }^{* * *} p<0.01$. The dependent variable is measured in percent. Runnerup refers to the second placed candidate with respect to the achieved vote share. District controls are measured at the year of the election. 
re Table 3: OLS regressions with (period-district) cluster-robust standard errors. Dependent variable: vote share of sample candidates in direct elections.

\begin{tabular}{|c|c|c|c|c|}
\hline & $\begin{array}{c}\text { All } \\
\text { parties } \\
(1)\end{array}$ & $\begin{array}{c}\text { All } \\
\text { parties } \\
(2)\end{array}$ & $\begin{array}{c}\text { Catch-all } \\
\text { parties } \\
(3)\end{array}$ & $\begin{array}{c}\text { Small } \\
\text { parties } \\
(4)\end{array}$ \\
\hline Attractiveness Score & $\begin{array}{l}0.120 \\
(1.34)\end{array}$ & $\begin{array}{c}0.239^{* * *} \\
(3.26)\end{array}$ & $\begin{array}{c}0.325^{* * *} \\
(3.95)\end{array}$ & $\begin{array}{l}0.250^{*} \\
(1.82)\end{array}$ \\
\hline \multicolumn{5}{|l|}{ Candidate controls } \\
\hline$\overline{\text { Log Age }}$ & $\begin{array}{c}2.688^{* * *} \\
(4.90)\end{array}$ & $\begin{array}{c}1.269^{* * *} \\
(2.69)\end{array}$ & $\begin{array}{l}0.404 \\
(0.86)\end{array}$ & $\begin{array}{c}2.426^{* * *} \\
(2.73)\end{array}$ \\
\hline $\mathrm{PhD}$ & $\begin{array}{l}0.292 \\
(1.12)\end{array}$ & $\begin{array}{c}0.565^{* * *} \\
(2.63)\end{array}$ & $\begin{array}{l}0.418^{*} \\
(1.73)\end{array}$ & $\begin{array}{l}0.145 \\
(0.38)\end{array}$ \\
\hline Male Candidate & $\begin{array}{l}-0.218 \\
(-1.03)\end{array}$ & $\begin{array}{l}0.266 \\
(1.48)\end{array}$ & $\begin{array}{c}0.104 \\
(0.57)\end{array}$ & $\begin{array}{c}0.646^{* *} \\
(2.11)\end{array}$ \\
\hline Incumbency Status & $\begin{array}{c}1.754^{* * *} \\
(6.56)\end{array}$ & $\begin{array}{c}2.075^{* * * *} \\
(8.91)\end{array}$ & $\begin{array}{c}1.859^{* * *} \\
(8.97)\end{array}$ & $\begin{array}{c}5.812^{* * *} \\
(3.04)\end{array}$ \\
\hline \multicolumn{5}{|l|}{ District controls } \\
\hline Turnout in District & $\begin{array}{l}-0.023 \\
(-0.90)\end{array}$ & $\begin{array}{c}0.013 \\
(0.56)\end{array}$ & $\begin{array}{c}0.086^{* * *} \\
(2.95)\end{array}$ & $\begin{array}{l}-0.083 \\
(-1.53)\end{array}$ \\
\hline Unemployment Rate & $\begin{array}{c}-0.098^{* * *} \\
(-3.73)\end{array}$ & $\begin{array}{c}-0.133^{* * *} \\
(-5.67)\end{array}$ & $\begin{array}{c}-0.168^{* * *} \\
(-6.08)\end{array}$ & $\begin{array}{l}0.052 \\
(1.00)\end{array}$ \\
\hline Male Population (Percent) & $\begin{array}{l}3.668 \\
(0.77)\end{array}$ & $\begin{array}{c}1.142 \\
(0.22)\end{array}$ & $\begin{array}{l}0.639 \\
(0.11)\end{array}$ & $\begin{array}{c}35.351 \\
(1.63)\end{array}$ \\
\hline District Size (in $1000 \mathrm{~km}^{2}$ ) & $\begin{array}{c}-0.283^{* * *} \\
(-3.17)\end{array}$ & $\begin{array}{c}-0.216^{* * *} \\
(-2.99)\end{array}$ & $\begin{array}{c}-0.489^{* * *} \\
(-3.86)\end{array}$ & $\begin{array}{c}0.505^{* * *} \\
(3.02)\end{array}$ \\
\hline Population Density (in 1000/ $\mathrm{km}^{2}$ ) & $\begin{array}{l}0.137^{*} \\
(1.85)\end{array}$ & $\begin{array}{l}0.106^{*} \\
(1.86)\end{array}$ & $\begin{array}{c}0.052 \\
(0.34)\end{array}$ & $\begin{array}{l}0.121 \\
(1.15)\end{array}$ \\
\hline \multicolumn{5}{|l|}{ Party controls } \\
\hline$\overline{\text { Party's Second vote share }}$ & $\begin{array}{l}1.121^{* * *} \\
(108.94)\end{array}$ & $\begin{array}{l}0.988^{* * *} \\
(74.07)\end{array}$ & $\begin{array}{l}0.994^{* * *} \\
(72.16)\end{array}$ & $\begin{array}{c}0.952^{* * *} \\
(31.48)\end{array}$ \\
\hline SPD & & $\begin{array}{c}0.414^{* *} \\
(2.08)\end{array}$ & $\begin{array}{c}0.417^{* *} \\
(2.15)\end{array}$ & \\
\hline Greens & & $\begin{array}{c}-4.697^{* * *} \\
(-9.03)\end{array}$ & & $\begin{array}{c}3.190^{* * *} \\
(7.06)\end{array}$ \\
\hline The Left & & $\begin{array}{c}-2.938^{* * *} \\
(-6.97)\end{array}$ & & $\begin{array}{c}3.602^{* * * *} \\
(8.69)\end{array}$ \\
\hline FDP & & $\begin{array}{l}-8.283^{* * *} \\
(-17.06)\end{array}$ & & \\
\hline Fixed period dummies & YES & YES & YES & YES \\
\hline Constant & $\begin{array}{c}-12.807^{* * *} \\
(-3.18) \\
\end{array}$ & $\begin{array}{l}-3.944 \\
(-1.00) \\
\end{array}$ & $\begin{array}{l}-6.073 \\
(-1.33) \\
\end{array}$ & $\begin{array}{r}-26.279^{*} \\
(-1.82) \\
\end{array}$ \\
\hline Observations & 1169 & 1169 & 844 & 325 \\
\hline $\mathrm{R}^{2}$ & 0.960 & 0.974 & 0.951 & 0.892 \\
\hline
\end{tabular}

Notes: $t$ statistics in parentheses, ${ }^{*} p<0.10,{ }^{* *} p<0.05,{ }^{* * *} p<0.01$. The dependent variable is measured in percent. Runnerup refers to the second placed candidate with respect to the achieved vote share. District controls are measured at the year of the election. 
re Table 7, panel (a): OLS regressions with (period-district) cluster-robust standard errors. Dependent Variable: dissension rate. MPs 2009-2013.

\begin{tabular}{|c|c|c|c|c|c|c|}
\hline & \multicolumn{2}{|c|}{ All MPs } & \multicolumn{2}{|c|}{ List MPs } & \multicolumn{2}{|c|}{ Direct MPs } \\
\hline & (1) & (2) & (3) & (4) & (5) & (6) \\
\hline Attractiveness & 0.138 & $0.258^{* *}$ & -0.020 & 0.155 & $0.267^{*}$ & $0.385^{* *}$ \\
\hline Score & $(1.32)$ & $(1.97)$ & $(-0.14)$ & $(0.78)$ & $(1.67)$ & $(2.19)$ \\
\hline \multicolumn{7}{|l|}{ MP controls } \\
\hline \multirow[t]{2}{*}{ Log Age } & & $2.031 * * *$ & & 1.405 & & $2.441 * *$ \\
\hline & & $(2.59)$ & & (1.30) & & $(1.99)$ \\
\hline \multirow[t]{2}{*}{ Male MP } & & 0.259 & & 0.326 & & -0.030 \\
\hline & & $(0.98)$ & & $(0.90)$ & & $(-0.07)$ \\
\hline \multirow[t]{2}{*}{$\mathrm{PhD}$} & & -0.040 & & -0.389 & & 0.295 \\
\hline & & $(-0.12)$ & & $(-0.96)$ & & $(0.64)$ \\
\hline \multirow[t]{2}{*}{ Years in Parl. } & & -0.030 & & -0.019 & & -0.053 \\
\hline & & $(-1.32)$ & & $(-0.51)$ & & $(-1.42)$ \\
\hline \multirow[t]{2}{*}{ Absence Rate } & & 0.059 & & 0.012 & & $0.119 *$ \\
\hline & & $(1.60)$ & & $(0.49)$ & & $(1.69)$ \\
\hline \multirow[t]{2}{*}{ Speeches } & & -0.032 & & -0.021 & & -0.013 \\
\hline & & $(-1.07)$ & & $(-0.66)$ & & $(-0.36)$ \\
\hline \multirow{2}{*}{$\begin{array}{l}\text { Oral } \\
\text { Contribution }\end{array}$} & & $0.245^{*}$ & & 0.101 & & $0.205^{*}$ \\
\hline & & $(1.88)$ & & $(1.03)$ & & $(1.79)$ \\
\hline \multirow[t]{2}{*}{ Function in Party } & & $-1.581^{* * *}$ & & $-1.816^{* * *}$ & & -1.727 \\
\hline & & $\begin{array}{c}(-3.07) \\
-1038 * *\end{array}$ & & $\begin{array}{l}(-3.49) \\
-0.195\end{array}$ & & $\begin{array}{l}(-1.47) \\
-1.990 * *\end{array}$ \\
\hline Minister & & $(-2.49)$ & & $(-0.46)$ & & $(-2.34)$ \\
\hline \multirow[t]{2}{*}{ State Secretary } & & $-0.853 * * *$ & & $-0.777^{* *}$ & & $-0.734 *$ \\
\hline & & $(-3.23)$ & & $(-2.01)$ & & $(-1.95)$ \\
\hline \multicolumn{7}{|l|}{ Party controls. } \\
\hline$\overline{\text { Safe D. }(3 \mathrm{P})}$ & & & & & & $\begin{array}{l}0.503 \\
(1.40)\end{array}$ \\
\hline \multirow[t]{2}{*}{ SPD } & & $1.172 * *$ & & $2.070 * * *$ & & 0.226 \\
\hline & & $(2.30)$ & & $(4.26)$ & & $(0.25)$ \\
\hline \multirow[t]{2}{*}{ Greens } & & $2.395 * * *$ & & $3.073 * * *$ & & $19.647^{* * *}$ \\
\hline & & (3.64) & & (4.99) & & $(6.06)$ \\
\hline \multirow[t]{2}{*}{ The Left } & & -0.386 & & 0.638 & & -0.375 \\
\hline & & $(-0.56)$ & & $(1.33)$ & & $(-0.39)$ \\
\hline \multirow[t]{2}{*}{ FDP } & & 0.059 & & 0.433 & & \\
\hline & & $(0.18)$ & & $(1.37)$ & & \\
\hline Constant & $1.313^{* * *}$ & $-8.312^{* *}$ & $2.436^{* * *}$ & -5.378 & 0.314 & $-10.627^{* *}$ \\
\hline & $(2.71)$ & $(-2.43)$ & $(3.50)$ & $(-1.11)$ & $(0.46)$ & $(-2.06)$ \\
\hline Observations & 621 & 621 & 322 & 322 & 299 & 299 \\
\hline $\mathrm{R}^{2}$ & 0.002 & 0.197 & 0.000 & 0.163 & 0.007 & 0.345 \\
\hline
\end{tabular}

Notes: $t$ statistics in parentheses, ${ }^{*} p<0.10,{ }^{* *} p<0.05,{ }^{* * *} p<0.01$. Absence Rate, Speeches and Years in Parliament are averages within the parliamentary term. Function in Party, Minister, and State Secretary are dummy variables that relate to the year in which the roll-call vote was taken. Safe D. (3 P) refers to a party having won the district in the previous three elections. 
re Table 7, panel (b): Bivariate probit regressions with (period-district) cluster-robust standard errors. Dependent variable: deviation dummy. MPs 2009-2013.

\section{Coefficient estimates (not shown in Table 7, panel (b)).}

\begin{tabular}{|c|c|c|c|c|c|c|}
\hline & \multicolumn{2}{|c|}{ All MPs } & \multicolumn{2}{|c|}{ List MPs } & \multicolumn{2}{|c|}{ Direct MPs } \\
\hline & (1) & (2) & (3) & (4) & (5) & (6) \\
\hline Attractiveness & 0.036 & $0.082^{* * *}$ & -0.001 & 0.049 & $0.081^{*}$ & $0.141^{* * *}$ \\
\hline Score & $(1.55)$ & $(2.81)$ & $(-0.05)$ & $(1.29)$ & $(1.86)$ & $(3.06)$ \\
\hline \multicolumn{7}{|l|}{ MP controls } \\
\hline \multirow[t]{2}{*}{ Log Age } & & $0.463^{* * *}$ & & 0.314 & & $0.806^{* * *}$ \\
\hline & & $(2.80)$ & & $(1.57)$ & & $(2.71)$ \\
\hline \multirow[t]{2}{*}{ Male MP } & & 0.026 & & 0.039 & & -0.015 \\
\hline & & $(0.49)$ & & $(0.60)$ & & $(-0.15)$ \\
\hline \multirow[t]{2}{*}{$\mathrm{PhD}$} & & -0.059 & & $-0.137^{*}$ & & 0.036 \\
\hline & & $(-0.89)$ & & $(-1.72)$ & & $(0.38)$ \\
\hline \multirow[t]{2}{*}{ Years in Parl. } & & 0.000 & & 0.001 & & -0.005 \\
\hline & & $(0.09)$ & & $(0.11)$ & & $(-0.75)$ \\
\hline \multirow[t]{2}{*}{ Absence Rate } & & 0.003 & & $-0.004^{*}$ & & $0.013^{* * *}$ \\
\hline & & $(1.13)$ & & $(-1.66)$ & & $(3.34)$ \\
\hline \multirow[t]{2}{*}{ Speeches } & & 0.001 & & -0.000 & & 0.004 \\
\hline & & $(0.20)$ & & $(-0.02)$ & & $(0.55)$ \\
\hline \multirow[t]{2}{*}{ Oral Contribution } & & $0.022^{* * *}$ & & 0.014 & & $0.036^{* * *}$ \\
\hline & & $(3.19)$ & & (1.57) & & $(5.53)$ \\
\hline \multirow[t]{2}{*}{ Function in Party } & & $-0.375^{* * *}$ & & $-0.427^{* * *}$ & & -0.353 \\
\hline & & $(-2.90)$ & & $(-2.80)$ & & $(-1.58)$ \\
\hline \multirow[t]{2}{*}{ Minister } & & $-0.762^{* * *}$ & & $-0.749^{* * *}$ & & $-0.875^{* * *}$ \\
\hline & & $(-4.64)$ & & $(-2.72)$ & & $(-4.16)$ \\
\hline \multirow[t]{2}{*}{ State Secretary } & & $-0.514^{* * *}$ & & $-0.436^{* * *}$ & & $-0.637^{* * *}$ \\
\hline & & $(-4.86)$ & & $(-3.14)$ & & $(-3.62)$ \\
\hline \multicolumn{7}{|l|}{ Party controls. } \\
\hline \multirow[t]{2}{*}{ Safe D. (3 P) } & & & & & & 0.092 \\
\hline & & $-0.361^{* * *}$ & & $-0.371^{* * *}$ & & $\begin{array}{l}(1.07) \\
-0.216^{* *}\end{array}$ \\
\hline coalition & & $\begin{array}{r}-0.001 \\
(-5.57)\end{array}$ & & $\begin{array}{r}-0.031 \\
(-4.09)\end{array}$ & & $\begin{array}{l}-0.10 \\
(-2.19)\end{array}$ \\
\hline Constant & $1.313^{* * *}$ & $-8.318^{* *}$ & $2.436^{* * *}$ & -5.393 & 0.314 & $-10.558^{* *}$ \\
\hline & $(2.71)$ & $(-2.43)$ & $(3.50)$ & $(-1.12)$ & $(0.46)$ & $(-2.05)$ \\
\hline Observations & 120951 & 120951 & 61675 & 61675 & 59276 & 59276 \\
\hline Adjusted- $\mathrm{R}^{2}$ & 0.001 & 0.048 & 0.000 & 0.031 & 0.005 & 0.079 \\
\hline
\end{tabular}


re Table 7, panel (b): Bivariate probit regressions with (period-district) cluster-robust standard errors. Dependent variable: deviation dummy. MPs 2009-2013.

Marginal effects at the mean.

\begin{tabular}{|c|c|c|c|c|c|c|}
\hline & \multicolumn{2}{|c|}{ All MPs } & \multicolumn{2}{|c|}{ List MPs } & \multicolumn{2}{|c|}{ Direct MPs } \\
\hline & (1) & (2) & (3) & (4) & $(5)$ & (6) \\
\hline Attractiveness Score & $\begin{array}{l}0.002 \\
(1.57)\end{array}$ & $\begin{array}{c}0.003^{* * *} \\
(2.86)\end{array}$ & $\begin{array}{l}-0.000 \\
(-0.05)\end{array}$ & $\begin{array}{l}0.002 \\
(1.31)\end{array}$ & $\begin{array}{l}0.003^{*} \\
(1.89)\end{array}$ & $\begin{array}{c}0.004^{* * *} \\
(3.02)\end{array}$ \\
\hline \multicolumn{7}{|l|}{ MP controls } \\
\hline Log Age & & $\begin{array}{c}0.017^{* * *} \\
(2.83)\end{array}$ & & $\begin{array}{l}0.015 \\
(1.59)\end{array}$ & & $\begin{array}{c}0.021^{* * *} \\
(2.74)\end{array}$ \\
\hline Male MP & & $\begin{array}{l}0.001 \\
(0.49)\end{array}$ & & $\begin{array}{l}0.002 \\
(0.60)\end{array}$ & & $\begin{array}{l}-0.000 \\
(-0.15)\end{array}$ \\
\hline $\mathrm{PhD}$ & & $\begin{array}{l}-0.002 \\
(-0.89)\end{array}$ & & $\begin{array}{l}-0.007^{*} \\
(-1.67)\end{array}$ & & $\begin{array}{l}0.001 \\
(0.38)\end{array}$ \\
\hline Years in Parl. & & $\begin{array}{l}0.000 \\
(0.09)\end{array}$ & & $\begin{array}{l}0.000 \\
(0.11)\end{array}$ & & $\begin{array}{l}-0.000 \\
(-0.75)\end{array}$ \\
\hline Absence Rate & & $\begin{array}{l}0.000 \\
(1.11)\end{array}$ & & $\begin{array}{l}-0.000^{*} \\
(-1.65)\end{array}$ & & $\begin{array}{c}0.000^{* * *} \\
(3.29)\end{array}$ \\
\hline Speeches & & $\begin{array}{l}0.000 \\
(0.20)\end{array}$ & & $\begin{array}{l}-0.000 \\
(-0.02)\end{array}$ & & $\begin{array}{l}0.000 \\
(0.55)\end{array}$ \\
\hline Oral Contribution & & $\begin{array}{c}0.022^{* * *} \\
(3.19)\end{array}$ & & $\begin{array}{l}0.014 \\
(1.57)\end{array}$ & & $\begin{array}{c}0.036^{* * *} \\
(5.53)\end{array}$ \\
\hline Function in Party & & $\begin{array}{c}-0.014^{* * *} \\
(-2.82)\end{array}$ & & $\begin{array}{c}-0.021^{* * *} \\
(-2.70)\end{array}$ & & $\begin{array}{l}-0.009 \\
(-1.57)\end{array}$ \\
\hline Minister & & $\begin{array}{c}-0.028^{* * *} \\
(-4.37)\end{array}$ & & $\begin{array}{c}-0.036^{* * *} \\
(-2.66)\end{array}$ & & $\begin{array}{c}-0.023^{* * * *} \\
(-3.83)\end{array}$ \\
\hline State Secretary & & $\begin{array}{c}-0.019^{* * *} \\
(-4.43)\end{array}$ & & $\begin{array}{c}-0.021^{* * *} \\
(-2.89)\end{array}$ & & $\begin{array}{c}-0.016^{* * *} \\
(-3.38)\end{array}$ \\
\hline Party controls. & & & & & & \\
\hline Safe D. (3 P) & & & & & & $\begin{array}{l}0.002 \\
(1.06)\end{array}$ \\
\hline $\begin{array}{l}\text { MP of govt. } \\
\text { coalition }\end{array}$ & & $\begin{array}{c}-0.014^{\text {*** }} \\
(-5.81)\end{array}$ & & $\begin{array}{c}-0.018^{* * *} \\
(-4.34)\end{array}$ & & $\begin{array}{l}-0.006^{* *} \\
(-2.20)\end{array}$ \\
\hline Constant & $\begin{array}{c}1.313^{* * *} \\
(2.71) \\
\end{array}$ & $\begin{array}{c}-8.318^{* *} \\
(-2.43) \\
\end{array}$ & $\begin{array}{c}2.436^{* * *} \\
(3.50) \\
\end{array}$ & $\begin{array}{l}-5.393 \\
(-1.12) \\
\end{array}$ & $\begin{array}{l}0.314 \\
(0.46) \\
\end{array}$ & $\begin{array}{c}-10.558^{* *} \\
(-2.05) \\
\end{array}$ \\
\hline Observations & 120951 & 120951 & 61675 & 61675 & 59276 & 59276 \\
\hline
\end{tabular}


re Table 8: Bivariate probit regressions with (period-district) cluster-robust standard errors. Dependent variable: deviation dummy. MPs 2009-2013.

Coefficient estimates of the attractiveness score for specific types of roll-call votes.

\begin{tabular}{|c|c|c|c|c|c|c|}
\hline \multirow[t]{2}{*}{ Type of roll-call votes } & \multicolumn{2}{|c|}{ All MPs } & \multicolumn{2}{|c|}{ List MPs } & \multicolumn{2}{|c|}{ Direct MPs } \\
\hline & $\begin{array}{c}\text { (1) } \\
\text { without } \\
\text { controls }\end{array}$ & $\begin{array}{c}\text { (2) } \\
\text { with } \\
\text { controls }\end{array}$ & $\begin{array}{c}\text { (3) } \\
\text { without } \\
\text { controls }\end{array}$ & $\begin{array}{c}(4) \\
\text { with } \\
\text { controls }\end{array}$ & $\begin{array}{c}\text { (5) } \\
\text { without } \\
\text { controls }\end{array}$ & $\begin{array}{c}\text { (6) } \\
\text { with } \\
\text { controls }\end{array}$ \\
\hline Top ten roll-call votes & $\begin{array}{l}0.063 \\
(1.45)\end{array}$ & $\begin{array}{l}0.123^{* *} \\
(1.99)\end{array}$ & $\begin{array}{l}0.018 \\
(0.28)\end{array}$ & $\begin{array}{l}0.103 \\
(1.08)\end{array}$ & $\begin{array}{l}0.121^{*} \\
(1.90)\end{array}$ & $\begin{array}{l}0.156^{*} \\
(1.88)\end{array}$ \\
\hline Military actions & $\begin{array}{l}0.036 \\
(0.71)\end{array}$ & $\begin{array}{l}0.075 \\
(1.14)\end{array}$ & $\begin{array}{l}-0.017 \\
(-0.34)\end{array}$ & $\begin{array}{l}0.010 \\
(0.15)\end{array}$ & $\begin{array}{l}0.115 \\
(0.92)\end{array}$ & $\begin{array}{l}0.212 \\
(1.57)\end{array}$ \\
\hline $\begin{array}{l}\text { Domestic policy } \\
\text { during the financial } \\
\text { and economic crisis }\end{array}$ & $\begin{array}{l}-0.153 \\
(-1.60)\end{array}$ & $\begin{array}{l}-0.106 \\
(-0.64)\end{array}$ & $\begin{array}{l}-0.447^{*} \\
(-1.93)\end{array}$ & $\begin{array}{l}-0.479^{*} \\
(-1.68)\end{array}$ & $\begin{array}{l}-0.022 \\
(-0.26)\end{array}$ & $\begin{array}{l}0.193 \\
(1.53)\end{array}$ \\
\hline $\begin{array}{l}\text { Domestic policy in } \\
\text { general }\end{array}$ & $\begin{array}{l}0.030 \\
(1.64)\end{array}$ & $\begin{array}{c}0.077^{* * *} \\
(3.65)\end{array}$ & $\begin{array}{l}0.013 \\
(0.58)\end{array}$ & $\begin{array}{l}0.075^{* * *} \\
(2.70)\end{array}$ & $\begin{array}{l}0.038 \\
(1.23)\end{array}$ & $\begin{array}{l}0.081^{* *} \\
(2.53)\end{array}$ \\
\hline Energy topics & $\begin{array}{l}-0.006 \\
(-0.13)\end{array}$ & $\begin{array}{l}0.043 \\
(0.66)\end{array}$ & $\begin{array}{l}0.005 \\
(0.10)\end{array}$ & $\begin{array}{l}0.043 \\
(0.54)\end{array}$ & $\begin{array}{l}-0.003 \\
(-0.04)\end{array}$ & $\begin{array}{l}0.044 \\
(0.43)\end{array}$ \\
\hline $\begin{array}{l}\text { European politics in } \\
\text { general }\end{array}$ & $\begin{array}{l}0.057 \\
(1.29)\end{array}$ & $\begin{array}{l}0.132^{* *} \\
(2.09)\end{array}$ & $\begin{array}{l}-0.001 \\
(-0.01)\end{array}$ & $\begin{array}{l}0.097 \\
(0.96)\end{array}$ & $\begin{array}{l}0.131^{* *} \\
(2.02)\end{array}$ & $\begin{array}{l}0.201^{* *} \\
(2.35)\end{array}$ \\
\hline General foreign policy & $\begin{array}{l}0.059 \\
(1.30)\end{array}$ & $\begin{array}{l}0.143^{*} \\
(1.89)\end{array}$ & $\begin{array}{l}-0.019 \\
(-0.26)\end{array}$ & $\begin{array}{l}0.043 \\
(0.41)\end{array}$ & $\begin{array}{l}0.145^{* *} \\
(2.32)\end{array}$ & $\begin{array}{l}0.263^{* *} \\
(2.48)\end{array}$ \\
\hline $\begin{array}{l}\text { European rescue } \\
\text { packages }\end{array}$ & $\begin{array}{l}0.062 \\
(1.33)\end{array}$ & $\begin{array}{l}0.139^{* *} \\
(2.09)\end{array}$ & $\begin{array}{l}0.003 \\
(0.04)\end{array}$ & $\begin{array}{l}0.108 \\
(1.02)\end{array}$ & $\begin{array}{l}0.138^{* *} \\
(2.04)\end{array}$ & $\begin{array}{l}0.206^{* *} \\
(2.28)\end{array}$ \\
\hline $\begin{array}{l}\text { Particular Greek } \\
\text { rescue packages I }\end{array}$ & $\begin{array}{l}0.023 \\
(0.50)\end{array}$ & $\begin{array}{l}0.107^{*} \\
(1.79)\end{array}$ & $\begin{array}{l}-0.088 \\
(-1.33)\end{array}$ & $\begin{array}{l}0.039 \\
(0.41)\end{array}$ & $\begin{array}{l}0.145^{* *} \\
(2.14)\end{array}$ & $\begin{array}{c}0.227^{* *} \\
(2.47)\end{array}$ \\
\hline $\begin{array}{l}\text { Particular Greek } \\
\text { rescue packages II }\end{array}$ & $\begin{array}{l}0.015 \\
(0.25)\end{array}$ & $\begin{array}{l}0.071 \\
(0.94)\end{array}$ & $\begin{array}{l}-0.127 \\
(-1.44)\end{array}$ & $\begin{array}{l}-0.026 \\
(-0.21)\end{array}$ & $\begin{array}{l}0.177^{* *} \\
(2.01)\end{array}$ & $\begin{array}{l}0.193^{*} \\
(1.65)\end{array}$ \\
\hline
\end{tabular}

Notes: $z$ statistics in parentheses, ${ }^{*} p<0.10,{ }^{* *} p<0.05,{ }^{* * *} p<0.01$. Coefficient estimates relating to table 8 . The sample documents the voting behavior of $621 \mathrm{MPs}$ in 218 roll-call votes. Top 10 roll-call votes were identified using Google Trends, the other roll-call votes are manually categorized. The dependent variable for all models is a dissension dummy which indicates whether a MP did not vote in line with the majority of the fellow party members in a specific roll-call vote. The coefficients in columns (1), (3) and (5) refer to the attractiveness score in a model without controls. The coefficients in columns (2), (4) and (6) were obtained from a model with controls for the MP's logarithmized age, gender and PhD title; the MP's average years in parliament, absence rate, speeches and oral contributions within the parliamentary term; whether the MP holds a function in the party, is a state secretary or minister during the year in which the roll-call vote was taken; whether the MP comes from a safe district which the MP's party has won in the previous three elections and whether the MP's party is part of the government coalition. 


\section{References}

Ahler, D. J., J. Citrin, M. C. Dougal and G. S. Lenz (2017). Can Your Face Win You Votes? Experimental Tests of Candidate Appearance's Influence on Electoral Choice. Political Behavior 39(1), 77-102.

Antonakis, J. and O. Dalgas (2009). Predicting elections: Child's play! Science 323(5918), 1183.

Asch, S. (1951). Effects of group pressure on the modification and distortion of judgments. In H. Guetzkow (Ed.), Groups, leadership and men. Pittsburgh, Carnegie Press, 177-190.

Banducci, S. A., J. A. Karp, M. Thrasher and C. Rallings (2008). "Ballot photographs as cues in low-information elections." Political Psychology 29(6): 903-917.

Becher, M. and U. Sieberer (2008). "Discipline, electoral rules and defection in the Bundestag, 1983-94." German Politics 17: 293-304.

Berggren, N., H. Jordahl and P. Poutvaara (2010). "The looks of a winner: Beauty and electoral success." Journal of Public Economics 94(1): 8-15.

Berggren, N., H. Jordahl and P. Poutvaara (2017). "The right look: Conservative politicians look better and their voters reward it." Journal of Public Economics 146: 7986.

Buckley, F., N. Collins and T. Reidy (2007). "Ballot Paper Photographs and LowInformation Elections in Ireland." Politics 27(3): 174-181.

Caplan, B. (2011). The myth of the rational voter: Why democracies choose bad policies, Princeton University Press.

Case, A and C. Paxson (2008). Stature and status: Height, ability, and labor market outcomes. Journal of Political Economy 116(3), 499-532.

Downs, A. (1957). "An economic theory of political action in a democracy." Journal of Political Economy 65(2): 135-150.

Dürrenmatt, F. (1962). Die Physiker. Arche, Zürich.

Efrain, M. G. and E. Patterson (1974). "Voters vote beautiful: The effect of physical appearance on a national election." Canadian Journal of Behavioural Science/Revue canadienne des sciences du comportement 6(4): 352. 
Hamermesh, D.S. (2006). "Changing looks and changing "discrimination": The beauty of economists." Economics Letters 93(3): 405-412.

Hamermesh, D.S. (2011). Beauty pays: Why attractive people are more successful, Princeton University Press.

Hamermesh, D.S., X. Meng and J. Zhang (2002). "Dress for success - Does primping pay?" Labour Economics 9(3): 361-373.

Hamlin, A. and C. Jennings (2011). Expressive political behavior: Foundations, scope and implications. British Journal of Political Science 41(3), 645-670.

Hart, W., V.C. Ottati and N. D. Krumdick (2011). "Physical attractiveness and candidate evaluation: A model of correction." Political Psychology 32(2): 181-203.

Hartley, L.P. (1960). Facial Justice. London, Hamish and Hamilton.

Herrmann, M. and S. Shikano (2015). "Attractiveness and Facial Competence Bias FaceBased Inferences of Candidate Ideology." Political Psychology 37(3): 401-417.

Hillman, A. (2010). Expressive behavior in economics and politics. European Journal of Political Economy 26(4), 403-418.

Hix, S. (2004). Electoral institutions ans legislative behavior: Explaining voting defection in the European Parliament. World Politics 56, 194-223.

Jackson, L., J. Hunter, C. Hodge (1995): Physical attractiveness and itellectual competence: A meta-analytic review. Social Psychology Quarterly 58(2), 108-122.

Jackson, D.J. and T.L. Huston. (1975). "Physical Attractiveness and Assertiveness." Journal of Social Psychology 96:79-84.

Jäckle, S. and T. Metz (2017). "Beauty contest revisited: The effects of perceived attractiveness, competence, and likeability on the electoral success of German MPs." Politics and Policy 45: 495-534.

Kauder, B. and N. Potrafke (2016). "Supermajorities and political rent extraction" Kyklos 69(1): 65-81.

Kauder, B. and N. Potrafke (2019). "Conservative politicians and voting on same-sex marriage" German Economic Review 20(4): e600-e617.

Kauder, B., N. Potrafke and M. Riem (2017). "Do parties punish MPs for voting against the party line?" CESifo Economic Studies 63(3): 317-332. 
King, A. and A. Leigh (2009). "Beautiful politicians." Kyklos 62(4): 579-593.

Kirchgässner, G. (1992). Toward a theory of low-cost decisions. European Journal of Political Economy 8(2), 305-320.

Klein, M. and U. Rosar (2005). "Physische Attraktivität und Wahlerfolg. Eine empirische Analyse am Beispiel der Wahlkreiskandidaten bei der Bundestagswahl 2002." Politische Vierteljahresschrift 46(2): 263-287.

Kunicova, J. and T. Remington (2008). Mandates, parties and dissent: Effect of electoral rules on parliamentary party cohesion in the Russian Duma, 1994-2003. Party Politics 14(5), 555-574.

Langlois, J.H., L. Kalakanis, A.J. Rubenstein, A. Larson, M. Hallam and M. Smoot (2010). "Maxims or myths of beauty? A meta-analytic and theoretical review." Political Psychological Bulletin 126(3): 390-423.

Lawson, C., G. S. Lenz, A. Baker and M. Myers (2010). "Looking like a winner: Candidate appearance and electoral success in new democracies." World Politics 62(04): 561-593.

Lee, D. S. (2001). "The electoral advantage to incumbency and voters' valuation of politicians' experience: A regression discontinuity analysis of elections to the U.S. House" NBER Working paper no 8441.

Lee, D. S., E. Moretti, and J. Butler (2004). "Do voters affect or elect policies? Evidence from the U.S. House" Quarterly Journal of Economics 119(03): 807-859.

Lenz, G. S. and C. Lawson (2011). "Looking the part: Television leads less informed citizens to vote based on candidates' appearance." American Journal of Political Science 55(3): 574-589.

Licata, C. and P.-G. Méon (2016). "Partisan stereotypes." Working Papers CEB 16.

Lutz, G. (2010). "The electoral success of beauties and beasts." Schweizerische Zeitschrift für Politikwissenschaft 16(3): 457-480.

Kirchgässner, G. (1992). "Towards a theory of low-cost decisions." European Journal of Political Economy 8: 305-320.

Maaser, N. and T. Stratmann (2018). "Election rules, legislators' incentives, and policy outcomes: Evidence from the mixed member system in Germany." European Journal of Political Economy 54: 227-239.

Maurer, M. and H. Schoen (2010). "Der mediale Attraktivitätsbonus." KZfSS Kölner Zeitschrift für Soziologie und Sozialpsychologie 62(2): 277-295. 
Mazzella, R. and A. Feingold (19949: 2The Effects of Physical Attractiveness, Race, Socioeconomic Status, and Gender of Defendants and Victims on Judgments of Mock Jurors: A Meta-Analysis." Journal of Applied Social Psychology 24(15), 1315-1338.

Oh, D., E. Shafir and A. Todorov (2020). "Economic status cues from clothes affect perceived competence from faces." Nature Human Behavior, forthcoming.

Olivola, C. and A. Todorov (2010). Elected in 100 milliseconds: Appearance-based trait inferences and voting. Journal of Nonverbal Behavior 34, 83-110.

Patzer, G. L. (2012). The physical attractiveness phenomena, Springer Science \& Business Media.

Rosar, U. (2009). "Fabulous Front-Runners. Eine empirische Untersuchung zur Bedeutung der physischen Attraktivität von Spitzenkandidaten für den Wahlerfolg ihrer Parteien." Politische Vierteljahresschrift 50(4): 754-773.

Rosar, U. and M. Klein (2010). And the Winner is... Ein Drei-Länder-Vergleich zum Einfluss der physischen Attraktivität von Direktkandidaten auf den Wahlerfolg bei nationalen Parlamentswahlen. Komparative empirische Sozialforschung, Springer: 307335.

Rosar, U. und M. Klein (2015). Politische Wahlen als Schöheitskonkurrenz: Urachen, Mechnismen, Befunde. Politische Vierteljahresschrift, Sonderheft 50, 217-240.

Rosar, U., M. Klein and T. Beckers (2008). "The frog pond beauty contest: Physical attractiveness and electoral success of the constituency candidates at the North RhineWestphalia state election of 2005." European Journal of Political Research 47(1): 6479.

Rule, N. O. and N. Ambady (2010). "Democrats and Republicans can be differentiated from their faces." PloS one 5(1): e8733.

Samochowiec, J., M. Wänke and K. Fiedler (2010). "Political ideiology at face value." Social Psychological and Personality Science 1(3): 206-213.

Savolainen, J., J.R. Brauer and N. Ellonen (2020). " Beauty is in the eye of the offender: Physical attractiveness and adolescent victimization." Journal of Criminal Justice 66(January-February): 101652.

Sieberer, U. (2010). "Behavioral consequences of mixed electoral systems: Deviating voting behavior of district and list MPs in the German Bundestag." Electoral Studies 29: 484-496. 
Sieberer, U. and T. Ohmura (2020). " Mandate type, electoral safety, and defections from the party line. The conditional mandate divide in the German Bundestag, 19492013." Party Politics, forthcoming.

Smith, R.H., W.G. Parrott, E.F. Diener, R.H. Hoyle, and S. Hee Kim (1999). "Dispositional envy." Personality and Social Psychology Bulletin 25(8): 1007-1020.

Snyder, M. and K. G. DeBono (1985). "Appeals to image and claims about quality: Understanding the psychology of advertising." Journal of Personality and Social Psychology 49(3): 586.

Snyder, C. and R. Zhuo (2018). Sniff test in economics: Aggregate distribution of their probability values and implications for publication bias. NBER Working Paper 25058.

Stockemer, D. and R. Praino (2017). "Physical attractiveness, electoral success and electoral systems: A natural experiment based on German election." British Journal of Politics and International Relations 19, 336-352

Stratmann, T. (2006). Party-line voting and committee assignments in the German mixed member system. Working Paper, George Mason University.

Stromberg, D. (2008): How the Electoral College influences campaigns and policy: The probability of being Florida. American Economic Review 98(3), 769-807.

Thames, F. (2005). A house divided: Part strength and the mandate divide in Hungary, Russia, and Ukraine. Comparative Political Studies 38(3), 282-303.

Todorov, A., A. N. Mandisodza, A. Goren and C. C. Hall (2005). "Inferences of Competence from Faces Predict Election Outcomes." Science 308(5728): 1623-1626.

Tullock, G. (1971). The charity of the uncharitable. Economic Inquiry 9, 379-392. 